\title{
IMPACT OF VISITS ON THE MICROCLIMATES OF CAVES EXPERIMENTAL EVIDENCE FROM ŠKOCJAN CAVES
}

\author{
VPLIV OBISKOV NA MIKROKLIMO JAM \\ REZULTATI MERITEV V ŠKOCJANSKIH JAMAH
}

\author{
Vanja DEBEVEC ${ }^{1} \&$ Jože RAKOVEC ${ }^{2}$
}

\begin{abstract}
UDC 551.44:551.584.6-057.67(497.4)

Vanja Debevec \& Jože Rakovec: Impact of visits on the microclimates of caves, Experimental evidence from Škocjan Caves Tourism activities in caves can result in changes in the microclimates of caves. The natural microclimate in closed caves is constant due to the balance between cave air and cave walls, while in open caves exchanges with outside air influence the microclimate. Visits to caves, especially in closed smaller caves, can thus endanger the natural balance if the microclimate does not return to natural conditions quickly enough.

Continuous monitoring of the temperature and concentration of carbon dioxide in Škocjan Caves enables the assessment of the impact of visits. For this purpose, we used data measured in the relatively closed Silent Cave, at the locations named Calvary (Kalvarija), Tent (Šotor), and Passage (Prehod) in 2016, and in the wide open Murmuring Cave, at the locations named Bridge (Most) and Rimstone Pools (Ponvice), in 2013. The outdoor air temperature, as measured at the Škocjan meteorological station on the surface plateau, was considered in both cases.

Along the tourist part of Škocjan Caves, the most closed part of the cave in Silent Cave is the location at Calvary, when the entrance doors through an artificially dug tunnel are closed. During the visits, the microclimate is subjected to draughts through open doors and to anthropogenic emissions. The data suggest that the influence of draughts predominates over direct anthropogenic emissions. In winter or on cold days air flows upwards and through the tunnel out of the cave, whereas in summer or on warm days it flows downwards. In such cases, the $\mathrm{CO}_{2}$ concentration decreases markedly due to the downwards chimney effect as the concentration in the outside air is much lower than in the cave. The data show that the temperature overnight and towards morning always returns to its natural value even in this
\end{abstract}

\begin{abstract}
Izvleček
UDK 551.44:551.584.6-057.67(497.4) Vanja Debevec \& Jože Rakovec: Vpliv obiskov na mikroklimo jam, rezultati meritev $v$ Škocjanskih jamah

Turistična dejavnost $\mathrm{v}$ jamah lahko spreminja naravno jamsko mikroklimo, ki je v zaprtih jamah nespremenljiva ob ravnovesju med jamskim zrakom in jamskimi stenami. V odprtih jamah so možne izmenjave z zunanjim zrakom. Obiski jam lahko predvsem $v$ zaprtih manjših jamah ogrozijo to ravnovesje, če se mikroklima ne vrne dovolj hitro v naravne razmere.

Stalni monitoring temperature in koncentracije ogljikovega dioksida v Škocjanskih jamah omogoča oceno posledic obiskov. Za lokacije v Tihi jami (Kalvarija, Šotor, Prehod) so bili uporabljeni podatki iz leta 2016, za morebitne vplive v Šumeči jami (Most in Ponvice) pa podatki iz leta 2013. V obeh primerih so bili upoštevani tudi podatki za zunanji zrak z meteorološke postaje Škocjan na površju.

V turističnem delu Škocjanskih jam je najbolj zaprt del jame lokacija v Tihi jami na Kalvariji, ko so vrata skozi umetno izkopan predor zaprta. Med obiski pa je mikroklima izpostavljena prepihu skozi odprta vrata in antropogenim emisijam. Podatki kažejo, da vpliv prepiha prevladuje nad vplivom neposrednih antropogenih emisij. Pozimi ali v hladnih dneh teče zrak navzgor in skozi predor iz jame, poleti ali $\mathrm{v}$ toplih dneh pa teče navzdol. $\mathrm{V}$ takih primerih se koncentracija $\mathrm{CO}_{2}$ izrazito zmanjša zaradi navzdolnjega učinka dimnika, saj je koncentracija v zunanjem zraku veliko nižja kot v jami. Podatki kažejo, da se temperatura čez noč in proti jutru vedno vrne na naravno vrednost tudi na tem precej majhnem prostoru $\mathrm{v}$ jami. Spremembe koncentracije $\mathrm{CO}_{2}$ trajajo dlje časa - do prvega obiska naslednje jutro, ko ob novem obisku nastane nova motnja.
\end{abstract}

${ }^{1}$ Biologist, employed in Public Service Agency Škocjan Caves Park until July 2020, Škocjan 2, 6215 Divača, Slovenia, e-mail:vanja.debevec@gmail.com

2 Retired professor, University of Ljubljana, Faculty of mathematics and physics, Chair of meteorology, Jadranska 19, 1000 Ljubljana, Slovenia, e-mail: joze.rakovec@fmf.uni-lj-si 
rather small location in the cave. The changes in $\mathrm{CO}_{2}$ concentration persist for a longer period, until the time of the first visit the next morning, when it is again perturbed by a new visit.

The data on time courses support the theoretically estimated characteristic of the exponential decline of disturbances backward towards natural conditions, depending on the size of a cave and on the efficiency of exchanges with its walls. For temperature, this characteristic time $\tau_{T}$ is about three to six hours at the Calvary site. The return of $\mathrm{CO}_{2}$ to natural conditions $\tau_{\mathrm{CO} 2}$ is longer and its estimate less reliable than the one for temperature.

In the wide-open and large Murmuring Cave, the impact of visits is negligible throughout the year. In this part of the cave we can observe the influence of external daily and annual changes, the amplitudes of which get smaller, and their phase lags bigger, deeper in the cave.

Keywords: Škocjan Caves, temperature, $\mathrm{CO}_{2}$, impact of visits, characteristic time of exponential decrease.
Podatki o časovnih potekih podpirajo teoretično predpostavko o eksponentnem upadu vpliva motenj nazaj proti naravnim razmeram, odvisno od velikosti jame in učinkovitosti izmenjav toplote, $\mathrm{CO}_{2}$, itd. $\mathrm{z}$ njenimi stenami. Za temperaturo je na Kalvariji ta značilni čas eksponentnega upada motenj približno od tri do šest ur. Vrnitev $\mathrm{CO}_{2}$ proti naravnim razmeram pa poteka dlje in ocena je manj zanesljiva od tiste za temperaturo.

V dokaj odprti in veliki Šumeči jami je vpliv obiska zanemarljiv skozi vse leto. $\mathrm{V}$ tem delu jame lahko opazujemo vpliv zunanjih dnevnih in letnih sprememb, katerih amplitude so čedalje globlje v jami vse manjše, njihov fazni zaostanek pa je vse večji.

Ključne besede: Škocjanske jame, temperatura, $\mathrm{CO}_{2}$, vpliv obiskov, karakteristični čas eksponentnega upada vpliva motenj

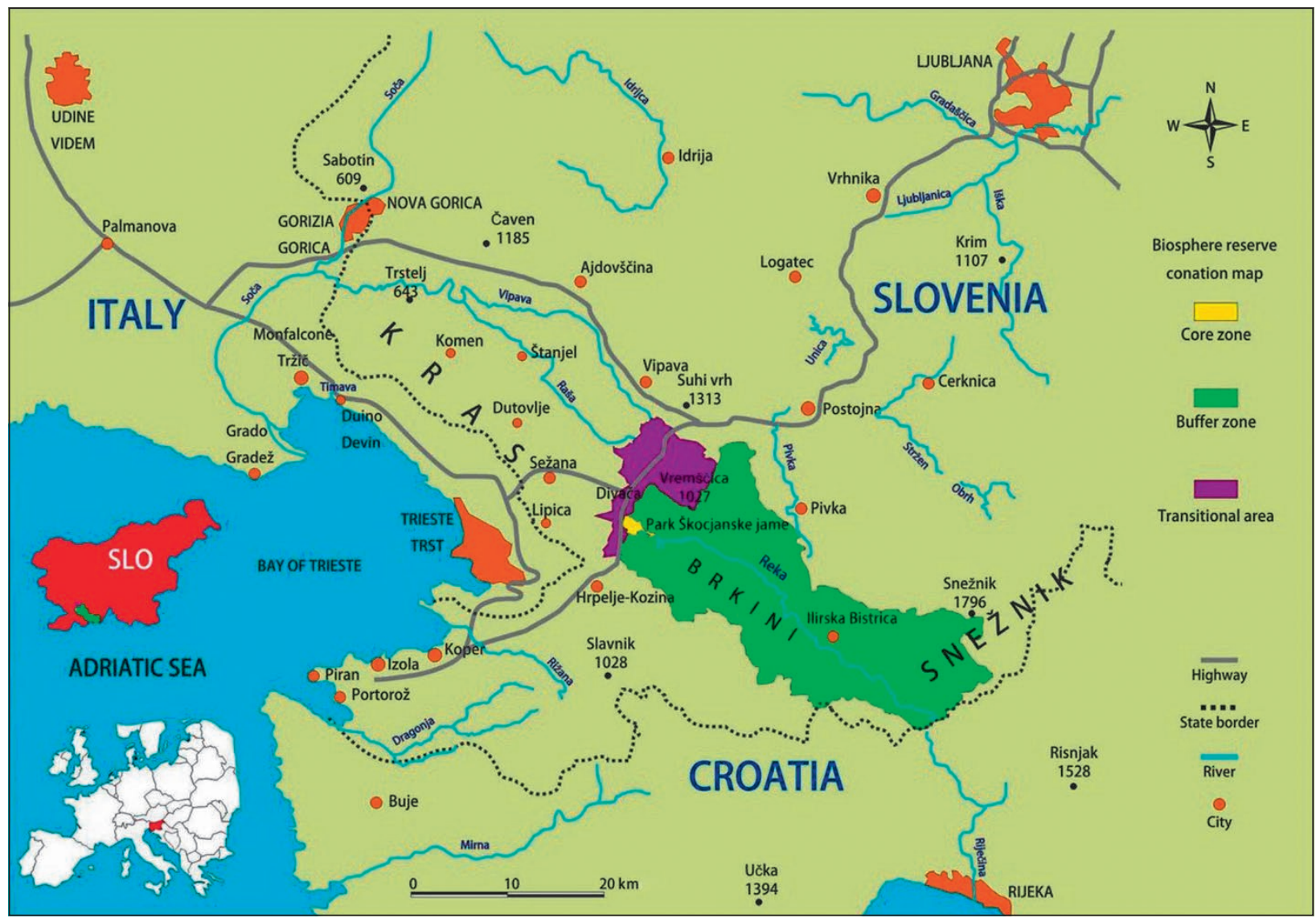

Figure 1: Location of Škocjan Caves in the Karst Biosphere Reserve. Škocjan Caves are located in the core zone, the small spot marked yellow. The buffer area is marked green, covering the water catchment area of the Reka River. The transition zone, covering the surface area above the part of the underground course of the river, is marked purple, courtesy of the Public Service Agency Škocjan Caves Park (Debevec et al., 2017). 


\section{INTRODUCTION}

Show caves face a major challenge in balancing visits with the need to protect nature. Visitor impact assessments (Farrell \& Marion, 2002; Manning, 2002, Eagles et al., 2002, Van der Donk \& Cotrell, 2002 ) follow the priorities of enabling visitors to enter the caves safely, and enjoy a unique experience, and at the same time protecting the vulnerable cave underground and adjacent surface areas (Castellani et al., 2007). However tourism activities always have environmental impacts (Hall \& Stephen, 2002; Salerno et al., 2013; Bella, 2002; CeballosLascuráin, 1996). Many research studies have been dedicated to describing the specific microclimatic conditions of caves (Zelinka, 2002; Fernández Cortés, 2004), since geomorphology plays an important part in evaluating cave-related phenomena (Šebela \& Turk, 2011; Bourge et al., 2014). A cave's microclimate has a delicate balance that contributes to the speleothems formations within it (Zupan Hajna, 2006; Ruan \& Hu, 2010). Many authors also attribute beneficial effects to specific microclimates, which are used for spelotherapeutic treatment of patients with respiratory diseases and allergies (Debevec, 2004).
However, the anthropogenic impact in caves causes disturbances to bats and other fauna (Kubešova, 2001; Furey \& Racey, 2016), due to excess lighting, and the growth of Lampenflora has also been observed (Spate, 2004; Mulec \& Kosi, 2009).

Protecting the delicate balance of underground ecosystems (Lobo, 2015; Cuevas-Gonzáles et al., 2010) is the key to assuring proper conservation measures. An efficient measures to achieve this has been shown to be limiting the number of people entering the caves (De Freitas, 2010; Calaforra et al., 2003), and thus helping the natural processes of the microclimate to regenerate without irreversible changes (Liñan et al., 2008; Fernández Cortés, 2004; Cañaveras et al., 2002).

The objective of this paper is the assessment of the influence of tourists on the microclimates of Škocjan Caves. Škocjan Caves are located in the Karst region of Slovenia, in the southwest of the country. They formed in early Cretaceous limestone strata at the juncture with impermeable Eocene flysch. The caves are an outstanding representation of the geological history of the Earth,

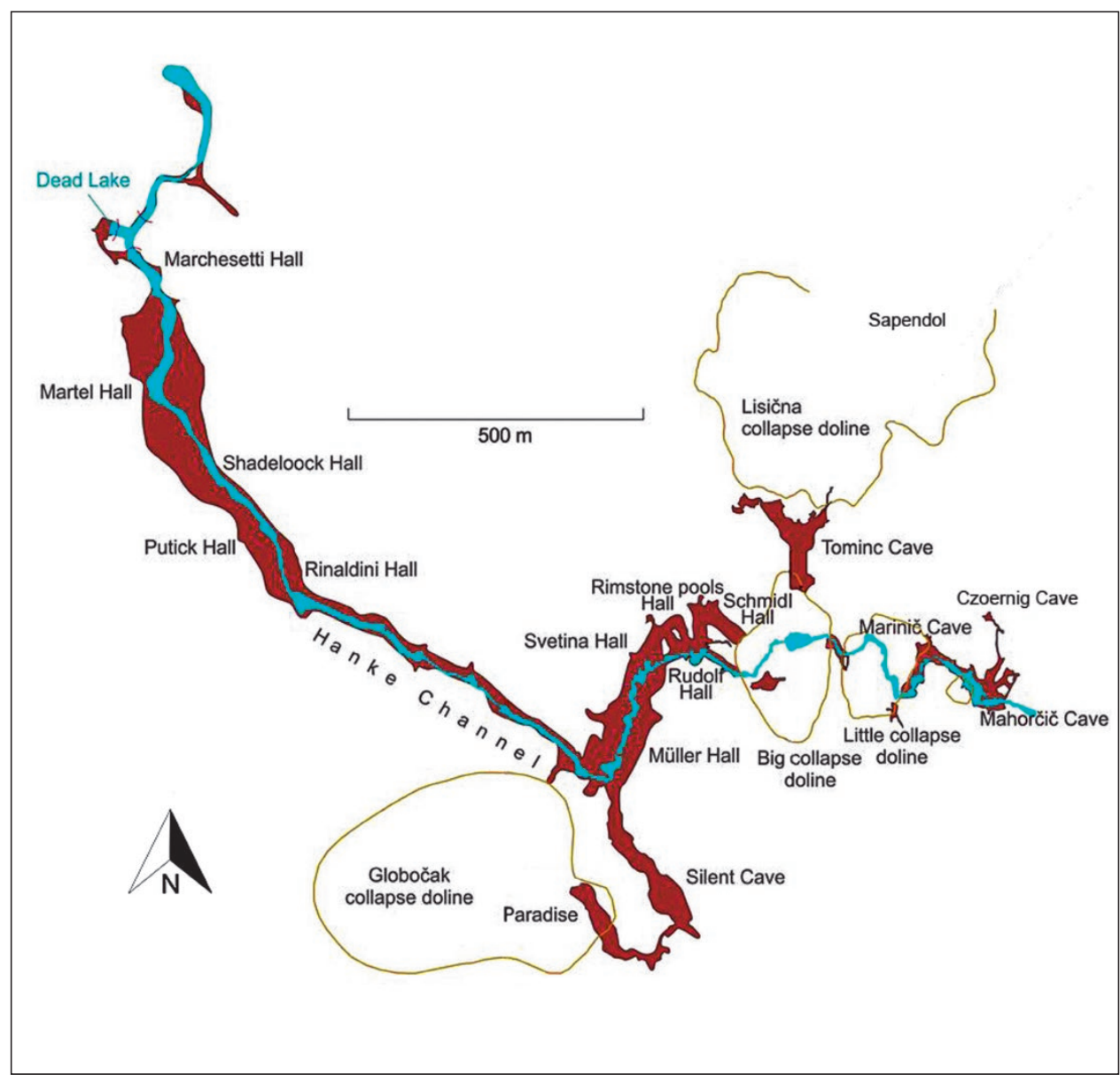

Figure 2: A ground plan of Škocjan Caves and its surroundings, courtesy of the Public Service Agency Škocjan Caves Park (Debevec et al., 2017). 
with a river forming vast underground spaces and speleothems (Mihevc, 2001).

The Reka River, with its $45-\mathrm{km}$ surface flow, has carved a canyon in limestone before entering the Škocjan Caves system. The river sinks into Škocjan Caves at 317 msl, runs through Mahorčičss Cave (Mahorčičeva Jama) and Mariničs Cave (Mariničeva Jama). It resurfaces in the passage through collapsed dolines, firstly at Little Dolina (Mala Dolina), and after that it reaches the lake in Great Dolina (Velika Dolina). There it finally sinks into the large underground gorge Murmuring Cave (Šumeča Jama), which is 250 long, up to $80 \mathrm{~m}$ wide, and a maximum of $120 \mathrm{~m}$ in height and has $870,000 \mathrm{~m}^{3}$ of volume and $16,700 \mathrm{~m}^{2}$ of surface area. The river runs through it beneath the Cerkvenik Bridge (Cerkvenikov most) into Hanke's Channel (Hankejev kanal) further on towards San Giovanni di Timavo (Štivan), until resurfacing as a tributary in the springs of the Timavo River in Italy, near Trieste (Kranjc, 2002; Debevec, 2004; Mihevc, 2017).

The upper part of the caves, away from the river course, is called Silent Cave (Tiha jama) - in contrast to Murmuring Cave, where the river flow is audible. It is 560 $\mathrm{m}$ in total length. From the highest point of Calvary to Tent (Šotor) its volume is over $23000 \mathrm{~m}^{3}$, the tunnel between Tent and Great Hall is narrow with $7700 \mathrm{~m}^{3}$, and Great Hall's volume makes it the largest in Silent Cave, at almost $65000 \mathrm{~m}^{3}$. Well preserved stalagmite formations may be observed in Silent Cave. Great Hall (Velika dvora- $n a)$ in this part is distinguished by huge stalagmites, also named "giants", that are up to 15 meters high (Debevec, 2004). The Murmuring Cave is much bigger and wide open to Great Dolina (Velika dolina).

Škocjan Caves have long been a learning site for speleologists due to their remarkable natural phenomena (Kranjc 2002) and also because of special protection measures that are in force at the site (Debevec et al., 2017). In 1986 the Škocjan Caves were designated as a UNESCO World Heritage Site.

The main pathway of the tourist guided tour starts with entering the caves in the Globočak collapsed doline, then going through the artificial tunnel to Silent Cave (Fig. 3). Visits proceed from the highest point of the tourist path at Calvary (Kalvarija), towards Tent (Šotor), and through Passage (Prehod) to the Murmuring Cave (Šumeča jama). From Cerkvenik's Bridge, the visiting path leads in the opposite direction of the river flow.

Tourism activity is becoming more popular in caves (Debevec et al., 2017). In order to apply adaptive management and provide efficient responses to any possible changes in the caves' conditions, a policy of limiting the number of visitors (Hamilton, 2002; Tičar et al., 2018) was adopted in Škocjan Caves. In order to derive an acceptable number of visitors, the monitoring of the caves' microclimates along the tourist pathway along Silent Cave and Murmuring Cave was established in 2006. That data is used for analyses in this paper.

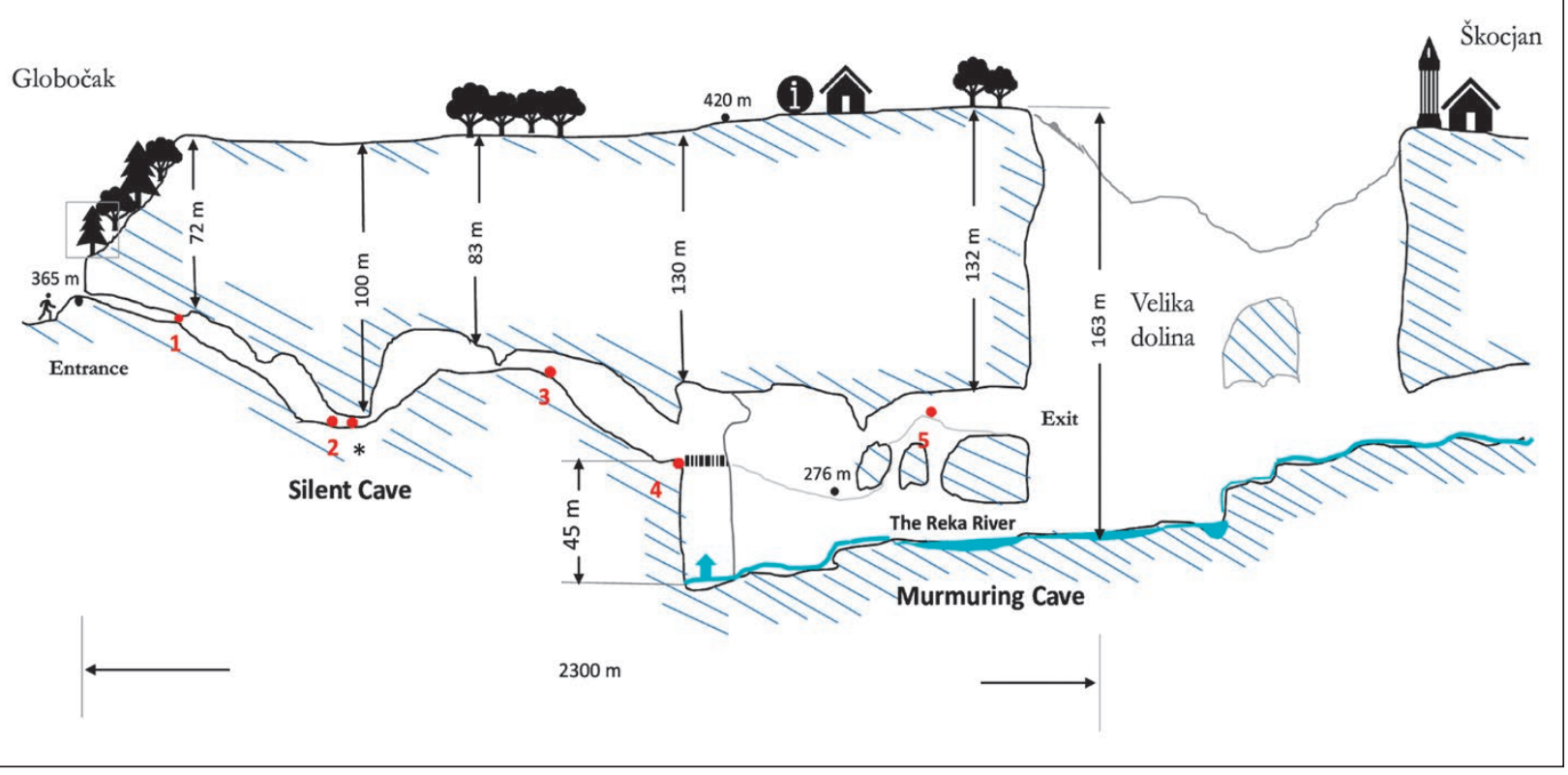

Figure 3: Cross-section along the tourist path with the locations of measurement stations: 1 - Calvary (Kalvarija) 350 msl, 2 - Tent (Šotor) 312 msl, 3 - Passage (Prehod) between the Silent and Murmuring Caves 298 msl, 4 - Bridge (Most) 298 msl, and 5 - Rimstone pools (Ponvice) 314 msl. Additional data used in the Discussions section was measured later at Labyrinth (Labirint), marked by an asterisk. Modified cross-section of Škocjan Caves, courtesy of the Public Service Agency Škocjan Caves Park (Debevec et al., 2017). 
The first goal of the analysis of the measured data is to determine the potential change in microclimate due to tourist visits, to see whether the observed data prove the impacts of such visits and what these could be. Moreover, it is also necessary to find out the time needed for microclimate to recover to its natural state (Pulido-Bosch, 1997). Another goal is to establish the link between the characteristic recovery time and geomorphological features of the cave focusing mainly on its dimensions.

As can be seen in Fig. 3, the Murmuring Cave is prone to influences of outer air through large openings to Great Dolina and the river flow entering the cave. On the other hand, Silent Cave is relatively closed, so Calvary, Tent, and Passage could be considered as locations within a closed cave.

\section{DATA AND METHODS}

\section{NUMBER OF VISITORS}

Guided tours for visitors are organized throughout the year. In January, February, March, November, and December there are two visits per day, at 10:00 and 13:00 local time (UTC +1 hour), with an additional visit on Sundays and festive days at 15:00. In April, May, and October (local summertime, UTC +2 hours) visitors can enter the cave at 10:00, 13:00, and 15:30. From June until the end of September, eight visits per day are organized every hour from 10:00 until 17:00.

The number of visitors per visit is for the needs of this paper evaluated based on the number of tickets sold prior to each of the visits, as well as the number of visitors being counted and recorded by the guides for every visit.

The time the visitors stay at particular locations in the Silent Cave is rather short and mostly lasts less than five minutes, though it can be extended if the group is large and the explanations of the guides are given in several languages. At locations in the Murmuring Cave this time is between five and ten minutes long. Larger groups need a longer time to enter the cave through the tunnel, which also results in the entrance doors in Globočak being opened for a longer time, and slower movement along the path.

The number of visitors to Škocjan Caves is higher in the summer months. The most popular visiting season starts in late April and lasts until the end of September. The month with the highest number of visits is August while there are only a few visitors during December, January, and February. Some data on the numbers of visitors from 2011 to 2016 is presented in Fig. 4.

\section{MEASURING STATIONS}

Measuring stations were set up in 2006 taking into account the geomorphological features of the halls and eventual changes in microclimatic conditions. Bearing in mind the need to protect a natural world heritage site, the measuring points were hidden as much as possible, with the need for an electric power supply playing a role in their actual location.

The first stop for tourists on their way through the caves is at Calvary, close to the artificial tunnel and the

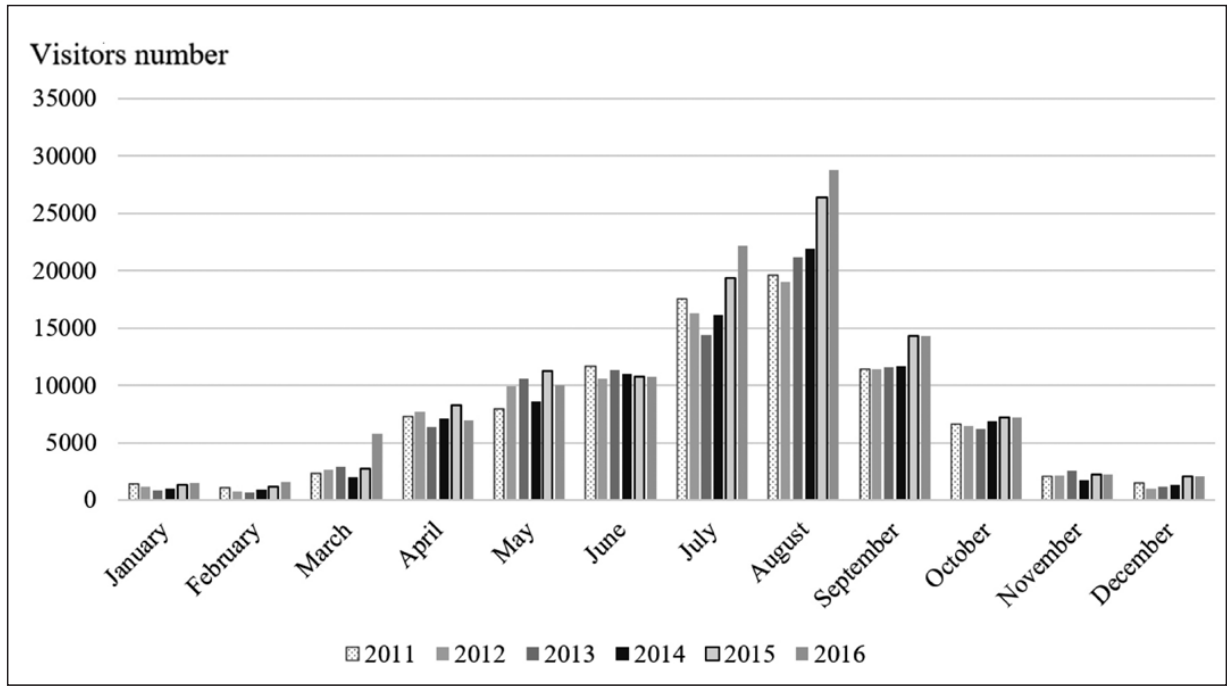

Figure 4: An overview of the number of visitors from 2011 to 2016 in different months of the year. 


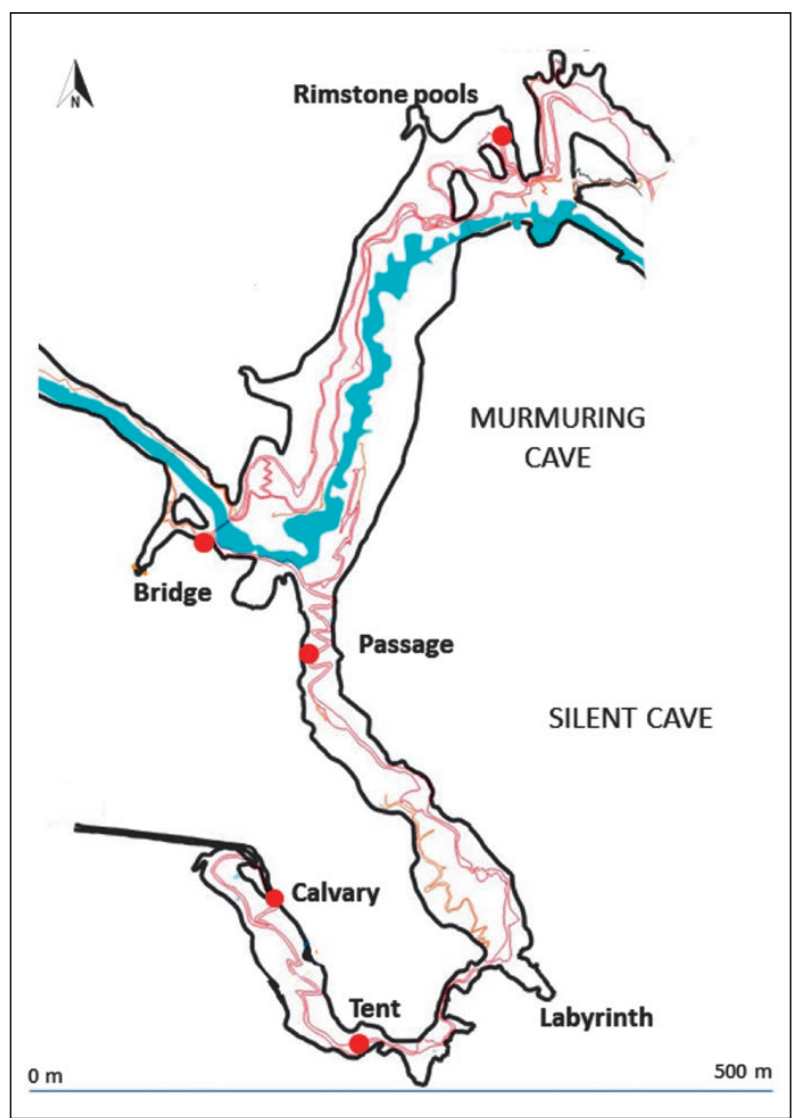

Figure 5: The locations of measurement stations 1- Calvary (Kalvarija $350 \mathrm{msl}$ ), 2 - Tent (Šotor $312 \mathrm{msl}$ ), 3 - Passage (Prehod) $329 \mathrm{msl}$ ), 4 - Bridge (Most $298 \mathrm{msl}$ ) and 5 - Rimstone pools (Ponvice) height: $314 \mathrm{msl}$ ). Additional data on draughts from Labyrinth (Labirint) (green circle) was measured in a joint project of the SCP, IZRK SAZU and MEIS. Modified plan of Škocjan Caves (courtesy of the Public Service Agency Škocjan Caves Park (Peric, 2019).

entrance doors. The tunnel is closed with double doors: one at the outer entrance to the tunnel, which has small openings at the top, and one at the entrance to the cave that opens towards Calvary, where visitors stop for an initial explanation and then proceed downwards toward Tent, where more information is given. After passing the Labyrinth and Great Hall in Silent Cave, they stop once more and then continue further towards the Passage - at the last part of the Silent Cave and the entrance to the Murmuring Cave. After $265 \mathrm{~m}$ the pathway passes by Rimstone pools and goes to Schmidl's Hall (Schmidlova dvorana) towards the exit in Great Dolina. The path along the Silent Cave is $560 \mathrm{~m}$ long, from the entrance to the Passage into the Murmuring Cave. The length of the path through the Murmuring Cave is $670 \mathrm{~m}$, start- ing from the Passage till the exit in the Great Dolina collapsed doline (Drole 2015, Debevec et al. 2017). Along this path a number of measuring stations were established, and those with data that we use in this study are presented in Fig. 5.

For the weather outside, and especially the temperature, the observations of the meteorological station in the village of Škocjan were used (ARSO 2019)

\section{MEASURING EQUIPMENT}

The temperature and $\mathrm{CO}_{2}$ concentration in Škocjan Caves were monitored at some places from 2006 on. However, in this study only the data measured in 2016 in the Silent Cave and the data from 2013 measured in the Murmuring Cave are analysed.

Alhborn Almemo instruments were used to measure temperature and $\mathrm{CO}_{2}$ at three locations in the Silent Cave, at Calvary, Tent, and Passage. Measurements were performed mainly in 5-minute time intervals (some also in 15-min intervals). Temperature measurements were obtained using a thermo-anemometer FVA935-TH5K2 Ahlborn Almemo (Almemo 1 2020). This is a hot wire sensor, measuring temperature and air speed velocity, but not the airflow direction, so only temperature data is used in our analysis. The sensor was installed on a metal mast $2 \mathrm{~m}$ above the ground. $\mathrm{CO}_{2}$ concentrations, which in the closed parts of the cave were close to $2000 \mathrm{ppm}$, were measured with a FYA600- $\mathrm{CO}_{2}$ Ahlborn Almemo (Almemo 2 2020) sensor. This is based on infrared optics with a measuring range from 0 to $25.000 \mathrm{ppm}$, and a declared accuracy of $50 \mathrm{ppm}$.

Measurements of temperature at two locations in the Murmuring Cave, at the Bridge and Rimstone Pools were performed using a Hanwell Rotronic HygroClip (Process Sensing Technologies) with a declared accuracy of $\pm 0.1{ }^{\circ} \mathrm{C}$ (Hanwell 2019).

As the changes over time in the variables caused by visits are more important than their exact absolute values for our analysis, the good temporal stability of instruments (i.e. repeatability) is more important than their absolute accuracy. As it is evident from Figs. 6 and 7 , the amplitudes of the variables' changes are sometimes rather small, but good repeatability of instruments still enables us to extract relevant information from the measurements, especially by filtering out some random errors after averaging over large samples of data.

The data from the external meteorological station Škocjan (ARSO), located on the surface between the Velika Dolina and the village of Škocjan, were measured according to WMO standards and archived in 30-minute intervals. 


\section{RESULTS}

\section{THE CLOSED PART OF THE CAVE}

To introduce the general microclimatic characteristics let us start with the temperature at Calvary, the location in the highest part of Silent Cave, which can be seen as a closed cave. It is not far from the doors of the tunnel, and except for the doors, being opened for a short time to let visitors enter the cave, the location is a closed one. Data for four months, representing four seasons, are presented in Fig. 6, together with outer air temperature data measured at Škocjan.

Figure 6 shows that in winter the temperature at Calvary does not change much. As in January there are only two visits per day with only a few dozen visitors, occasionally more on holidays, the temperature at Calvary stays almost constant and around $12.1{ }^{\circ} \mathrm{C}$, while the outer air at Škocjan experiences significant variations from -10 to $+13^{\circ} \mathrm{C}$ due to changing weather. In March the number of visits is two per day (on Sundays and festive days three per day) and the number of visitors rises to between a hundred to several hundred. This causes daily tempera-
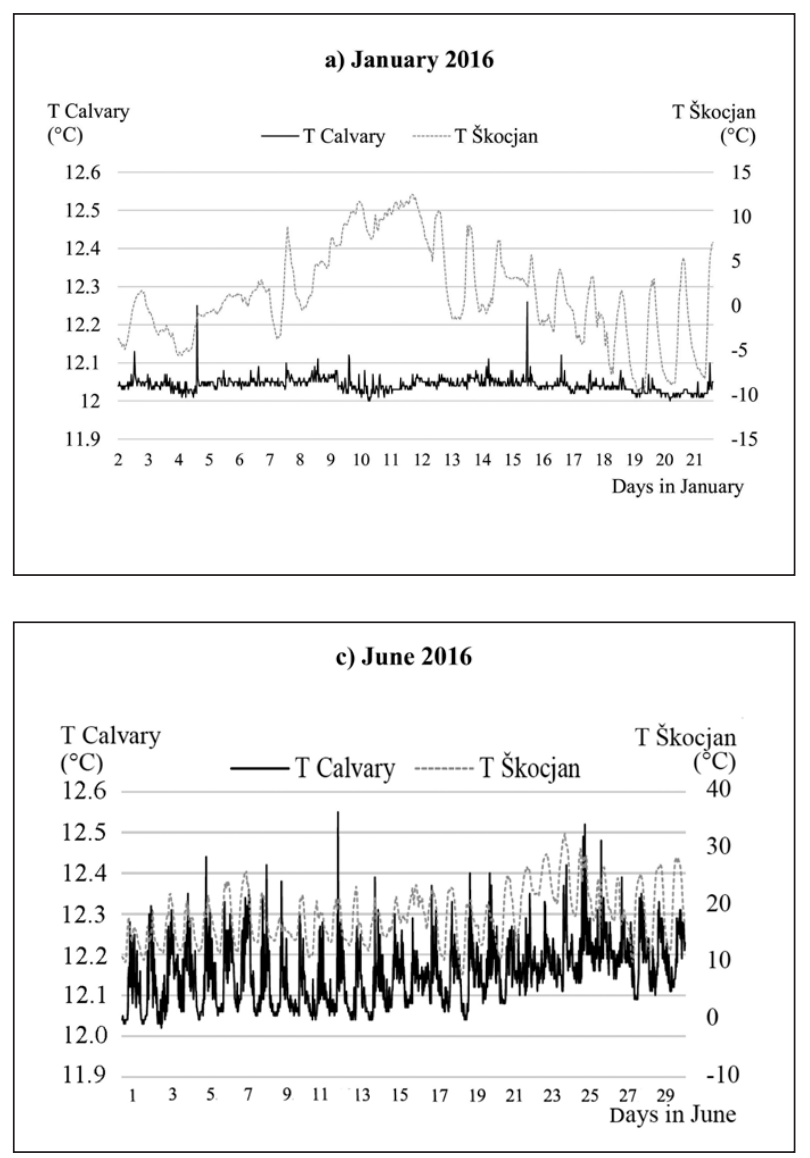

ture changes in the cave of some tenths of a degree, especially towards the end of the month. The daily changes in the cave become stronger and more regular in June, where there are several visits per day with a lot of visitors, and this cause daily temperature variations of about half a degree. In June there is also a weak but steady increase in the average temperature in the cave at Calvary. In October there are again fewer visitors, and thus daily changes in the cave are somewhat smaller, but still clearly evident.

The data suggest that daily changes are connected with visits. Without visits, the temperature in this rather closed part of the cave would stay relatively constant even in the warm part of the year, despite of significant changes outside.

\section{A closer look at the change fluctuations in temperature and $\mathrm{CO}_{2}$ concentration in Silent Cave}

A close look at temperature fluctuations connected with the visits the winter with only a few visitors is not very
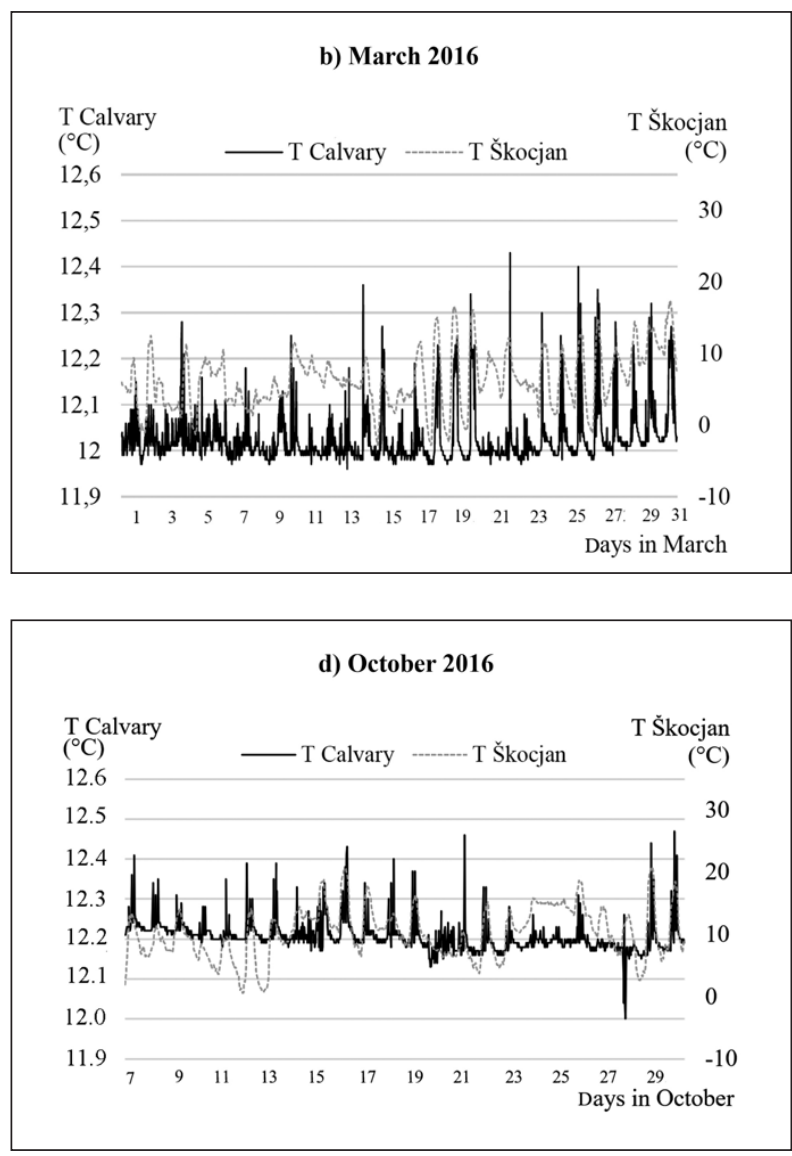

Figure 6: Temperatures at Calvary and the outer air at Škocjan in January A), March B), June C) and October D) 2016. 
appropriate. On the other hand, in summer there are many visitors, with visits every hour - so that a new visit starts before the disturbed cave's microclimate returns to the natural conditions. It is thus best to analyse the October data, as there are only three visits per day, but there

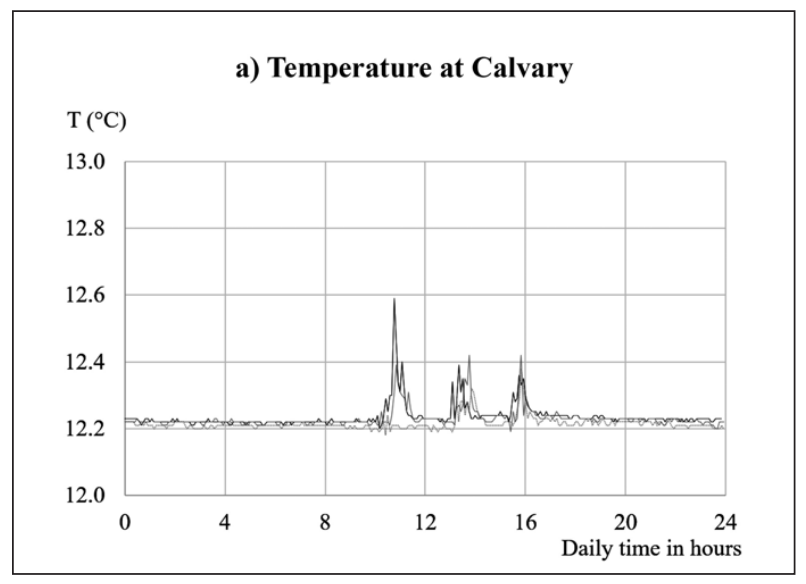

c) $\mathrm{CO}_{2}$ concentration at Calvary

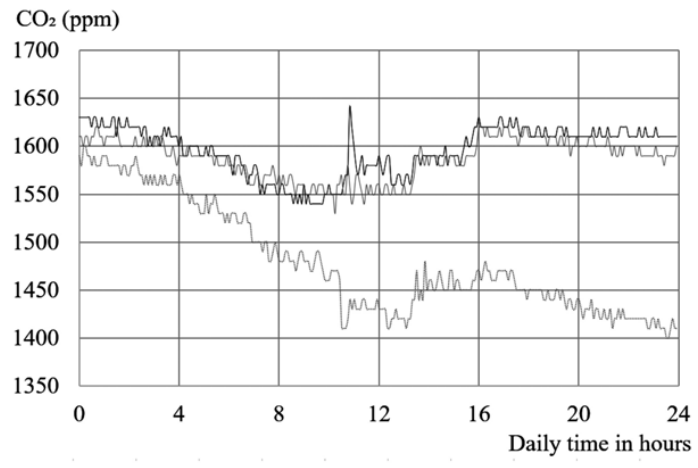

are still clear change fluctuations in temperature and $\mathrm{CO}_{2}$ concentration around the times of visits.

At some locations the temperature fluctuations are also evident from the data for each separate day; for example, at the rather closed location at Calvary, while at less closed locations, as for example at Tent, each indi-

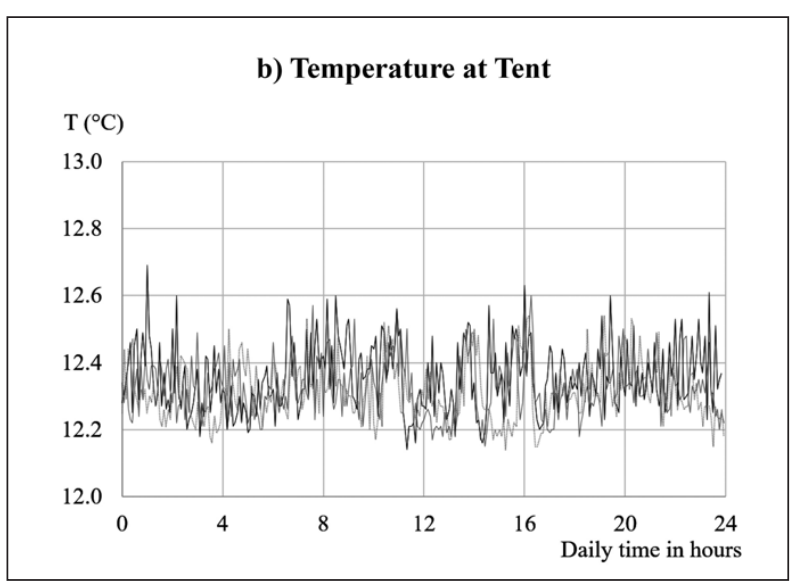

d) $\mathrm{CO}_{2}$ concentration at Tent

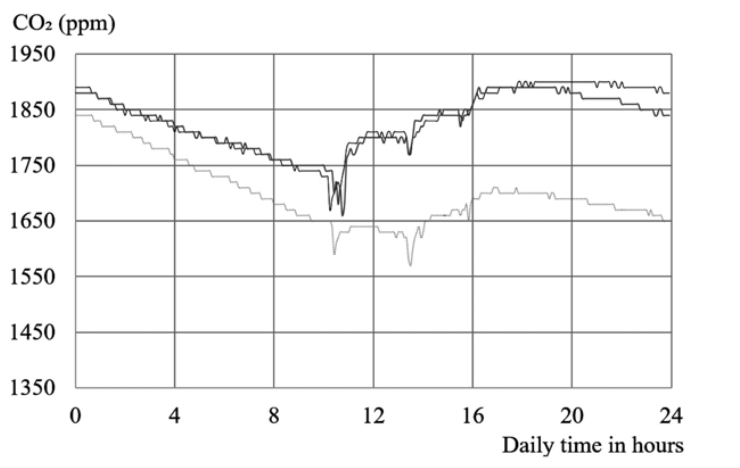

Figure 7: Temperature and $\mathrm{CO}_{2}$ concentration daily courses on three days, $8^{\text {th }}, 9^{\text {th }}$ and $10^{\text {th }}$ October 2016, at Calvary $(A, C)$ and Tent $(B, D)$.
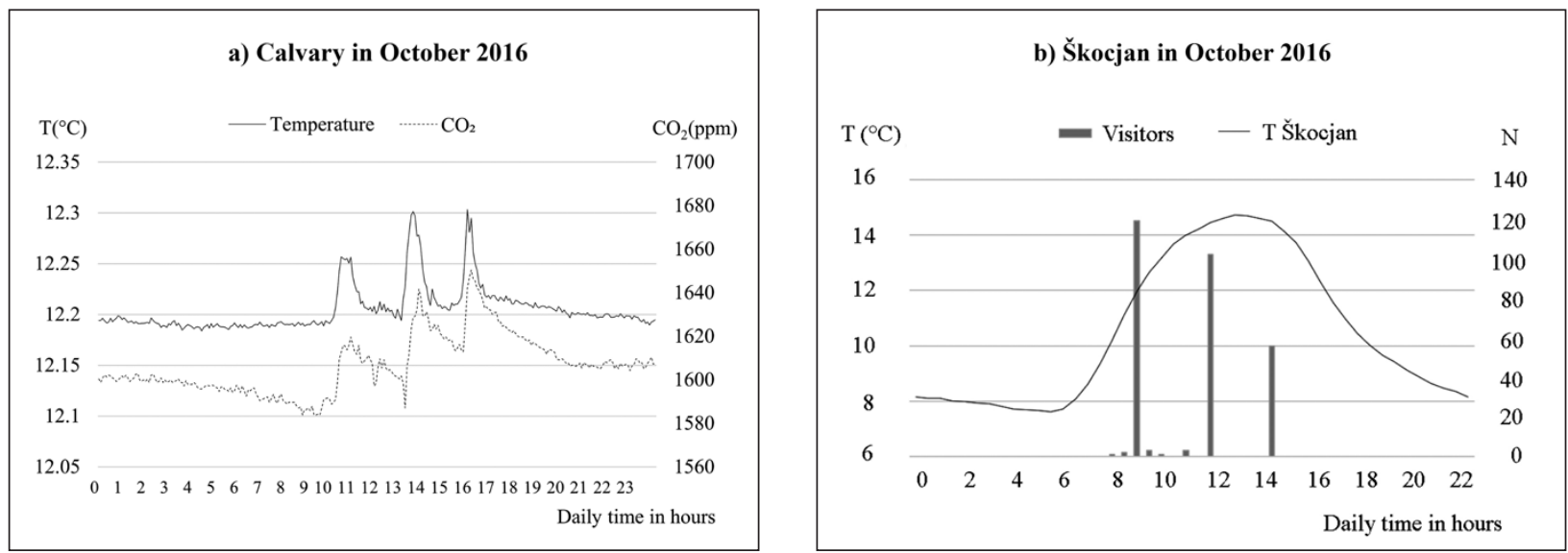

Figure 8.: Daily changes in monthly averaged temperature $\mathrm{T}$ (black line) and of $\mathrm{CO}_{2}$ concentration (grey dotted line) at Calvary (Kalvarija) in October 2016 A), and the monthly averaged outer air temperature at Škocjan, and the number of visitors N B). 
vidual day shows many irregular variations, seeming to be close to random noise as seen in Figure $7 \mathrm{~b}$.

These examples show that it is appropriate to consider the monthly averages of the daily courses of variables, as averaging eliminates at least some random noise. Thus, for each measurement period (e.g., 00:05, $00: 10,00: 15$, etc.) we calculate the average monthly value for that time and compose the monthly average of the daily course from these.

At Calvary averaging over the month (Fig. 8) filters out small, random variations, shows more clearly the change fluctuations of temperature and of $\mathrm{CO}_{2}$ at the times of visits, as well as the recovery decrease back to the basic concentration after the last visit of the day. The October 2016 monthly averaged temperature at Calvary varies around $12.2{ }^{\circ} \mathrm{C}$, with fluctuations of about $0.1^{\circ} \mathrm{C}$. On the other hand, at Tent, as well as at Passage, it is only after averaging that the link between visits and change fluctuations becomes clear: a lot of the random up or down variations are removed, some noise is still present, but magnitudes are considerably smaller (Figs. 11 with more details later). If at Calvary it could perhaps still be appropriate to analyse the data for individual days, at Tent, as well at Passage, only very noisy information could be inferred from individual day's data.

Three major changes in temperature per day are clearly evident from Fig. 8 that coincide with the times of visits. Temperature increases are rapid, for about 0.1 ${ }^{\circ} \mathrm{C}$, followed by a slower return to normal. Temperature differences between the outer air and cave are almost zero at the time of morning visit, at the first afternoon visit it is about $3{ }^{\circ} \mathrm{C}$, and somewhat smaller at the second afternoon visit. The $\mathrm{CO}_{2}$ concentrations in general also increase at each of the visits. What seems to be of interest is the sharp initial decrease of concentration at the time of the first afternoon visit, followed by an increase. The temperature change fluctuations calm down during the night, several hours before the first morning
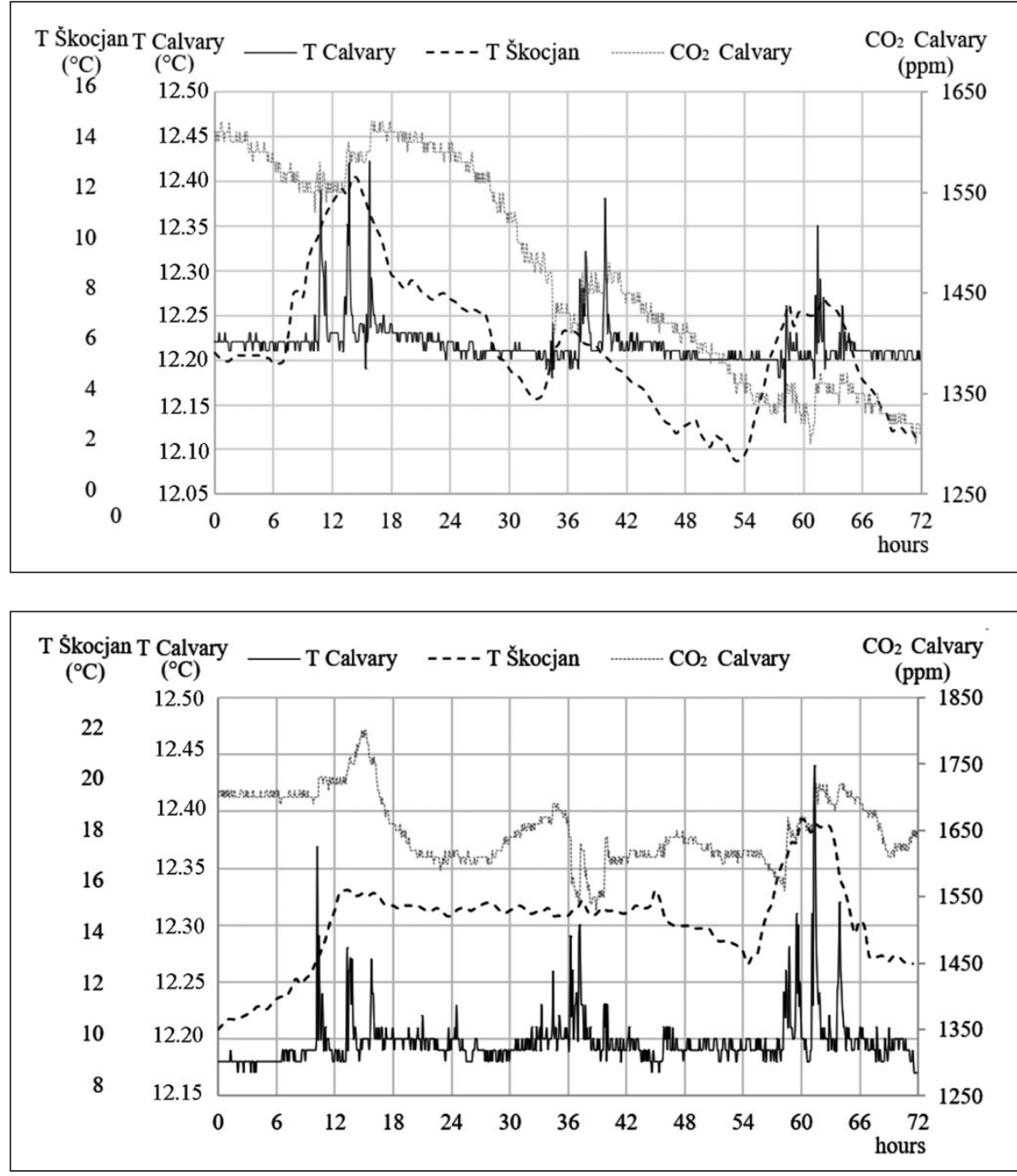

Figure 9: Three warm days, October 24-26, suggesting the downdraught chimney effect in the cave and the intrusion of outer air into Calvary when the doors open. The outer air temperature in Škocjan (black dotted line), the change fluctuations in temperature (black line) and $\mathrm{CO}_{2}$ concentration (grey dotted line) at Calvary.
Figure 10: Similar to Figure 9, but for three colder days, October 9-11, favouring the updraught chimney effect, thus bringing to Calvary the air from lower parts of the cave. 
visit, while the $\mathrm{CO}_{2}$ concentration disturbances do not. The decrease in concentration persists into the morning and is interrupted by the new disruption at the time of the first morning's visit.

The upwards-downwards chimney effects could be better understood if we look separately at warm and cold days. There were in October 2106 several days when the outer air was warm all day. In such cases opening the doors should favour the downdraught chimney effect, sucking the outer air into Calvary. But there were also cold days in that October when we should expect an updraught from lower parts of the cave. Some examples of this are seen in Figs. 9 and 10.

Looking at the temperature data, there are no major differences between the updraught/downdraught cases, except maybe for the magnitude of sudden changes in temperature. As far as $\mathrm{CO}_{2}$ concentrations are considered the differences are obvious. On warm days the downdraught chimney effect causes intrusion of the warm outer air into Calvary, which increases the temperature and, especially on the second and third days, reduces the $\mathrm{CO}_{2}$ concentration - as the concentration in the outer air is several times smaller than in the cave. On cold days there are only weak decreases in $\mathrm{CO}_{2}$ concentration at the times of visits, but with a steady decrease. The temperature also increases on these days at the times of visits. If we speculate that the upwards chimney effect when the doors are opened is the cause of all these change fluctuations, the temperature deeper in the cave should be somewhat higher, and the $\mathrm{CO}_{2}$ concentration lower.

This can be further supported with data measured at Tent in the Silent Cave and Passage at the beginning of the Murmuring Cave, as presented in Figs. $11 \mathrm{a}$ and b.

The average monthly temperature at Tent, deeper in the Silent cave and thus relatively closed, is $12.3^{\circ} \mathrm{C}$ about $0.1{ }^{\circ} \mathrm{C}$ warmer than at Calvary. At Passage, closer to Murmuring Cave the monthly average temperature is
13.2 ${ }^{\circ} \mathrm{C}$, much warmer, around $1{ }^{\circ} \mathrm{C}$ warmer than at Calvary, perhaps due to the influence from outside through the wide open Murmuring Cave. The $\mathrm{CO}_{2}$ concentration at Tent is close to $2000 \mathrm{ppm}$, which is much higher than at Calvary. The speculation on the influence from outside could be further supported by the much lower $\mathrm{CO}_{2}$ concentration at Passage - well below 1000 ppm, which is only half that at Calvary.

All three change fluctuations at the times of visits show an increase of temperature at Tent and decrease at Passage. At Tent a steady decrease in the $\mathrm{CO}_{2}$ concentration is observed during the night until the first morning visit, with a sharp and short decrease at these morning visits, followed by a general increase from then on. As is evident in the monthly average data, it seems this is a very regular process. There are only slight $\mathrm{CO}_{2}$ change fluctuations at the noon and the afternoon visits. At Passage, closer to the open Murmuring Cave, the $\mathrm{CO}_{2}$ concentration is much lower. It is also moderately decreasing during the night until the first morning visit, but change fluctuations that could be connected to visits are here stronger and move in the opposite direction, increasing the concentration.

As already noted: all three change fluctuations at visit times show increases in temperature at Tent and decreases at Passage, and the opposite for $\mathrm{CO}_{2}$. We will try to give some explanation for this, at first glance unusual behaviour later in Discussion subsection.

Characteristic times for temperature and $\mathrm{CO}_{2}$ to decrease to natural conditions in a closed cave

The "natural conditions" in caves are those that are not influenced by visits and are constant due to the balanced exchanges between the air in the cave and the walls of the cave (Badino 1995; James 2004). In the management of visits to caves, the return to natural conditions must be assured and relatively quick, otherwise, the microcli-

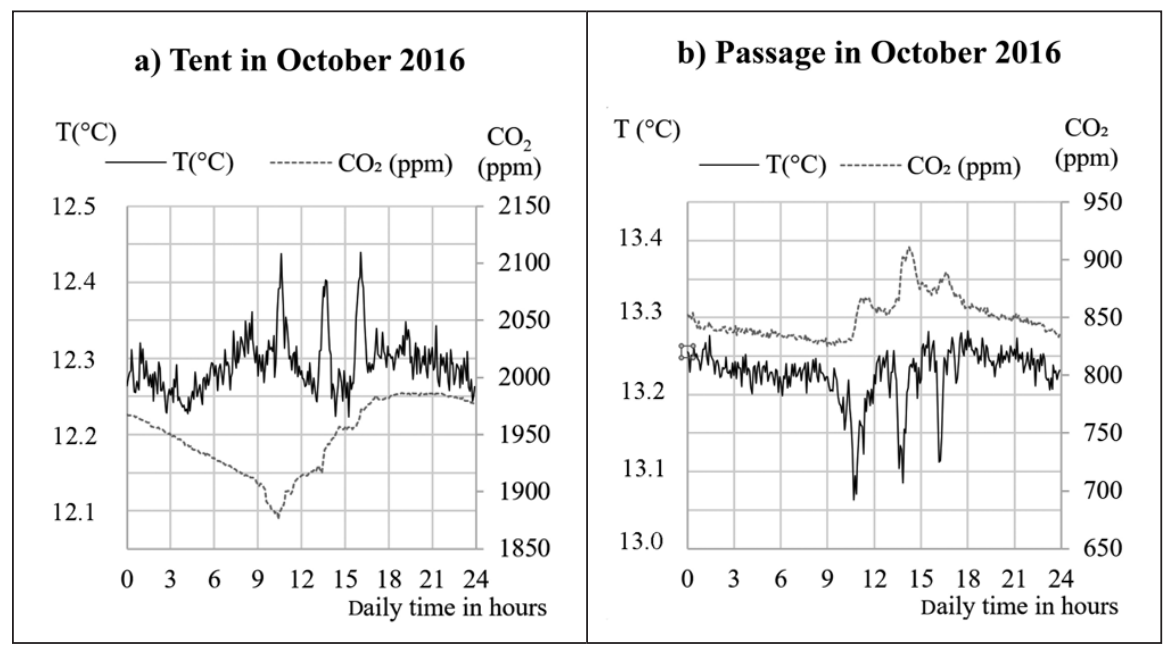

Figure $11 A$ and B: Monthly average of daily courses of temperature (black line) and $\mathrm{CO}_{2}$ concentration (grey dotted line) at Tent and Passage in October 2016. Both locations are some 25 m deeper than Calvary, Tent some $180 \mathrm{~m}$ away and Passage some 200 m away. 
mate might experience irreversible changes, damaging the process of speleothems growth (Dreybrodt, $2004 \mathrm{a}$, b; Cigna, 2002; Cigna, 2004; Cañaveras et al., 2002; De Freitas, 2010; Fernández Cortés, 2004). As explained in previous sections, Calvary can be seen as "closed cave" when the doors are closed. When the doors are open, there could be an important influence of the draught through the tunnel. As the volume of this part of a cave is relatively small, anthropogenic emissions might also contribute to change fluctuations.

After heat or $\mathrm{CO}_{2}$ spreads and equalizes over the entire volume $V$ of the air in a cave, the final sink is the walls of the cave with an area $A$. That leads to an exponential decrease of change fluctuations $\Delta T$ and $\Delta c$ over time, moving back towards the natural values $T_{n a t}$ and $c_{\text {nat }}$ :

$$
\begin{aligned}
& T(t) T_{n a t}+T\left(1-e^{\frac{-t}{\tau_{T}}}\right), \tau_{T}=\frac{V c_{p}}{h_{T} A}, \\
& c(t)=c_{n a t}+c\left(1-e^{\frac{-t}{\tau_{c}}}\right), \tau_{C O 2}=\frac{V}{h_{c} A} .
\end{aligned}
$$

The expressions $\tau_{T}=\frac{V c_{p}}{h_{T} A}$ and $\tau_{C O 2}=\frac{V}{h_{c} A}$ thus follow from the idea that the final sinks of change fluctuations (heat or $\mathrm{CO}_{2}$ ) are due to exchanges between the air and walls. Under such an assumption the characteristic times of the exponential decrease of change fluctuations back to natural conditions depend on the overall air-walls heat exchange coefficients $h_{T}$ and gas exchange coefficient $h_{c}$, on the dimensions of the cave V/A and the air density and heat capacity, $c_{p}$ but not on the magnitude of the perturbation (for more explanation consider, for example, Rakovec (2020)). Analysing the changes in time of temperature and $\mathrm{CO}_{2}$ concentration after a visit, one can get the estimates of characteristic decreasing times $\tau_{T}$ and of $\tau_{\mathrm{CO} 2}$.

The most appropriate way to analyse the characteristic recovery times is to look at the time period after the last visit of the day during the night, free of any disturbances. The initial perturbed temperature is the one measured an hour or two after the last visit of the day, when
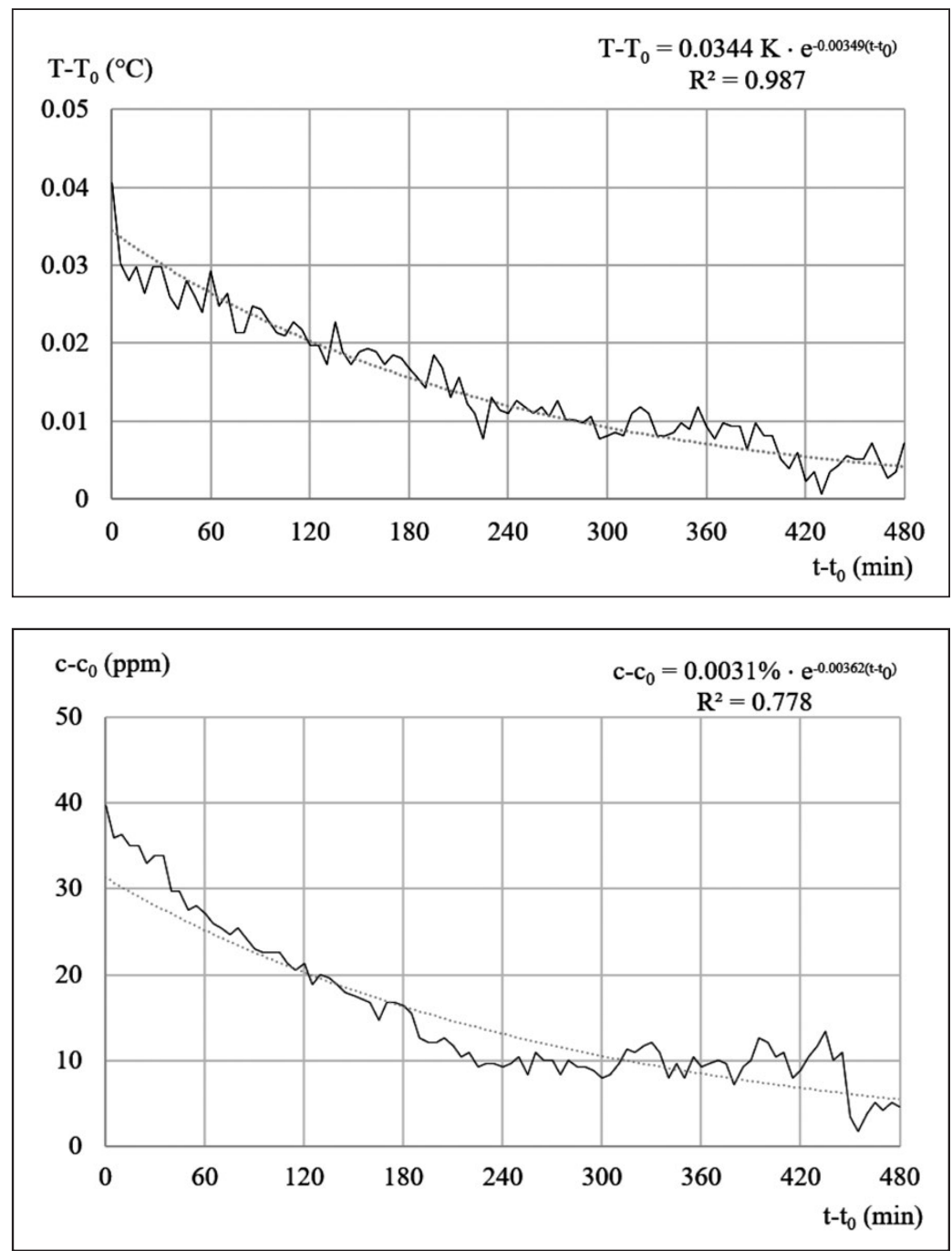

Figure 12: Monthly average $\Delta T=T-T_{0}$ decrease after the last daily visit at Calvary during the 8 hours' starting from 16:30 in October 2016, with $T_{0}=12.19^{\circ} \mathrm{C}$, which gives $\tau=3.8$ hours. The data are fitted by an exponential function; the quality of fit is estimated by $R^{2}$, and $\tau$ is estimated by the regression between $\ln \Delta T$ and time.

Figure 13: Similar to Fig. 12, but for the $\mathrm{CO}_{2}$ concentration; with the monthly average $\Delta c=c-c_{0}$, and $c_{0}=1600 \mathrm{ppm}$, this gives $\tau=7.1$ hours. 
the spread over the whole cave is already finished and the air has calmed down. The final natural value should be estimated from the data. In our case that is rather easy for the temperature. Simply by looking at the data series, like the one in Fig. 8, it looks that temperature stabilizes at around 02:00 or 03:00 overnight and stays more or less constant almost until the first morning visit. That constant value $T_{0}$ is a rather good estimate for the $T_{n a t}$. For the initial time of the analyses, we take one hour after the last daily visit, for the initial temperature the one being measured at that time, and for the final $T_{0}$ the average temperature from 02:00 to 07:00. Unfortunately, it is not so simple for the $\mathrm{CO}_{2}$ concentration, as the choice of $c_{\text {nat }}$ is less evident - the concentration does not stabilize during the night, but continues to decrease until the first morning visit (Fig. 8). So here the choice of $c_{0}$ is more subjective. Nevertheless, the examples of both decreases at Calvary in October 2016 are presented in Figs. 13 and 14. The data fitting was done in Excel in which the default option of fitting with an exponential function offers only a few decimals for $1 / \tau$, and thus an alternative approach was used: the logarithm of the exponential equations is applied and the linear regression between $\ln \Delta \mathrm{T}$ and time is carried out.

The determination of characteristic time $\tau_{T}$ of the exponential decrease to the natural values depends mostly on the asymptotic value $T_{0}$ to which the values tend after a long time, on the time period, being analysed, and, on $\mathrm{R}^{2}$ that evaluates the quality of fitting the data with the analytical function. In general: the higher the asymptotic value $T_{0}$, the steeper is $\ln \left(\mathrm{T}-T_{0}\right)$ versus time and the shorter $\tau_{T^{*}}$ Analysing the temperature data for October 2016 in 8-hour intervals (starting one hour after the last daily visit at 16:30 until 00:30), it was found that increas- ing the final $T_{0}$ for $0.01{ }^{\circ} \mathrm{C}$ causes a less pronounced decrease with an almost doubling of the characteristic time $\tau$ - from around 4 hours to more than 6 hours. Analysing shorter, or longer, or partly shifted time intervals, results in only moderate changes in the characteristic time of about half an hour or so. This depends mainly on whether some of the data intervals contain significantly different data than other intervals. Such testing of sensitivity of estimates of $\tau$ on input parameters extends the basic estimate for temperature of $\tau_{T} \approx 3.8$ hours to an interval ranging from approx. 3.5 hours to approx. 6.5 hours. The high $\mathrm{R}^{2}$ does not necessarily mean better estimate of $\tau$, it only evaluates how good the fitting of data is by the analytical function.

The quality of estimating the characteristic time for the $\mathrm{CO}_{2}$ concentration $\tau_{\mathrm{CO} 2}$ is mainly hampered by not being able to estimate $c_{0}$ reliably. If we look again at Fig. 8 it is evident that the $\mathrm{CO}_{2}$ concentration first diminishes, then stabilizes for a couple of hours around midnight, and then continues to decrease till the first morning visit - so the $\tau_{\mathrm{CO}_{2}}=1 / 0.00234 \mathrm{~min}=7.12$ hours - twice as long as the characteristic time for temperature, which represents only a rough estimate for the $\mathrm{CO}_{2}$ exponential recovery. With regard to sensitivity testing for $\mathrm{CO}_{2}$, the results are valid and show the same general conclusions as for temperature. Nevertheless, the characteristic time of the exponential decrease of $\mathrm{CO}_{2}$, change fluctuations, although its value is less reliable, is much slower than the decrease of the temperature change fluctuations.

\section{DAILY CHANGES IN THE LARGELY OPEN PARTS OF CAVES}

At the opening to the Great Dolina collapsed doline is the Murmuring Cave, exposed to strong influences from the
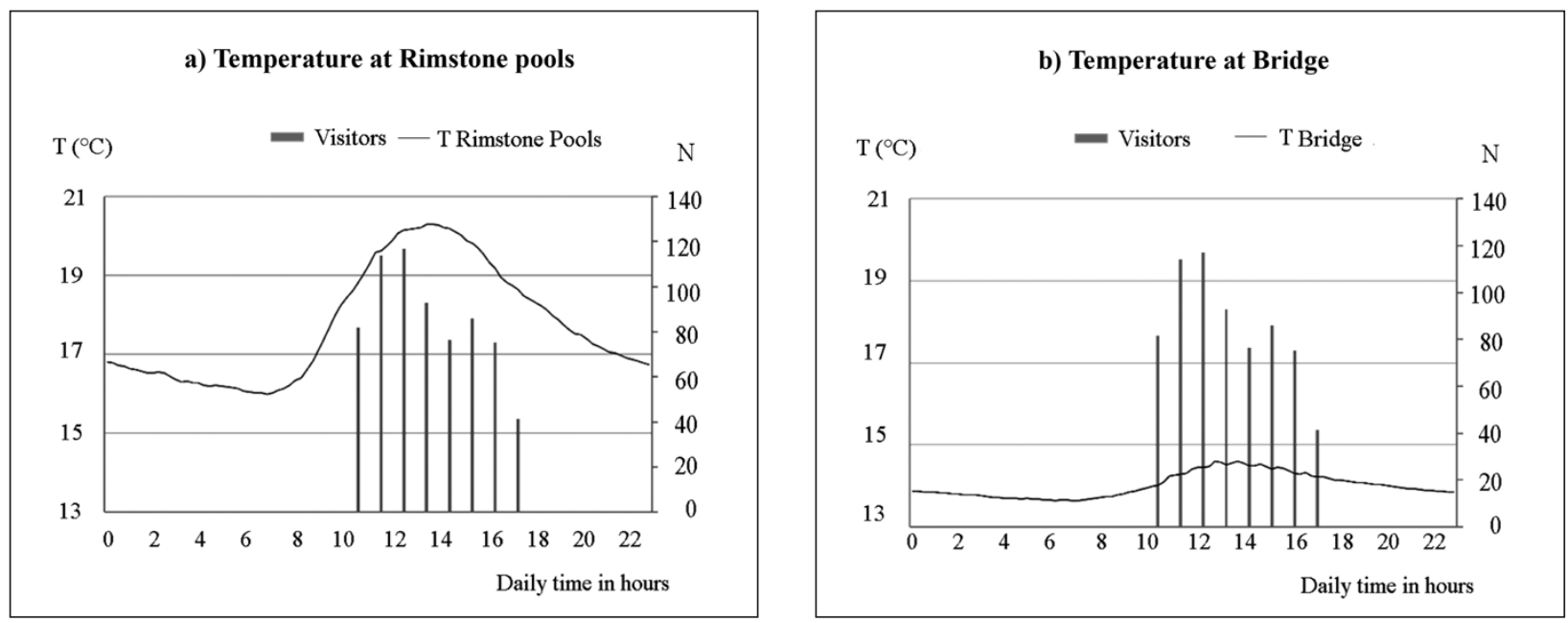

Figure 14: Monthly average of temperature T daily course in August 2013, and of the monthly number of visitors $\mathrm{N}$ at the Rimstone Pools (Ponvice), the average monthly temperature is $17.8^{\circ} \mathrm{CA}$ ) and at the Bridge (Most), the average monthly temperature is $14.0^{\circ} \mathrm{C} \mathrm{B)}$. 
outside, and this part of the cave system is rather large: according to Drole (2015), it has a volume of $870,000 \mathrm{~m}^{3}$. The area most exposed to outer influences is the measuring location at the Rimstone Pools (Ponvice), not far from Great Dolina. The location at the Bridge (Most), somewhat deeper in the cave, together with that at Rimstone Pools, represent two examples of locations in a wide open cave. Due to the great volume and open location, the data show almost no influence of visits in this part of Škocjan Caves. As seen from daily temperature courses in Figs. 14 and 15, the impact of visits in the Murmuring Cave is below detectability.

These examples prove that in the large and wide open Murmuring Cave there are no significant impacts of visits on the microclimatic conditions. The slight variations that were found could be caused by changes in airflow, rather than by anthropogenic heat sources.

Temperature data from the Rimstone Pools and Bridge, together with temperature data from outer air measurements in Škocjan, are presented in Fig. 15. From this it is evident, without any deeper analysis, that high amplitudes of daily temperature variations outside (Škocjan), in October often exceeding 20 degrees (or even higher), become smaller and smaller deeper and deeper into the cave: at Rimstone Pools being only a half as great as the outer ones, and deeper at the Bridge reaching only a few degrees.

As good data for comparison between these measuring stations is available for August 2013, we use this to analyse the influence of outer daily variations on the cave. With regard to the time delays of daily courses, these should be greater when going deeper into a cave (see e.g., Rakovec 2020). The simplest estimates for time delays could be to compare the times at which maxima and minima occur at different locations. Such comparisons offer only partial information on phase shifts that could be improved by some more comprehensive method. One of the better estimates is to calculate the values

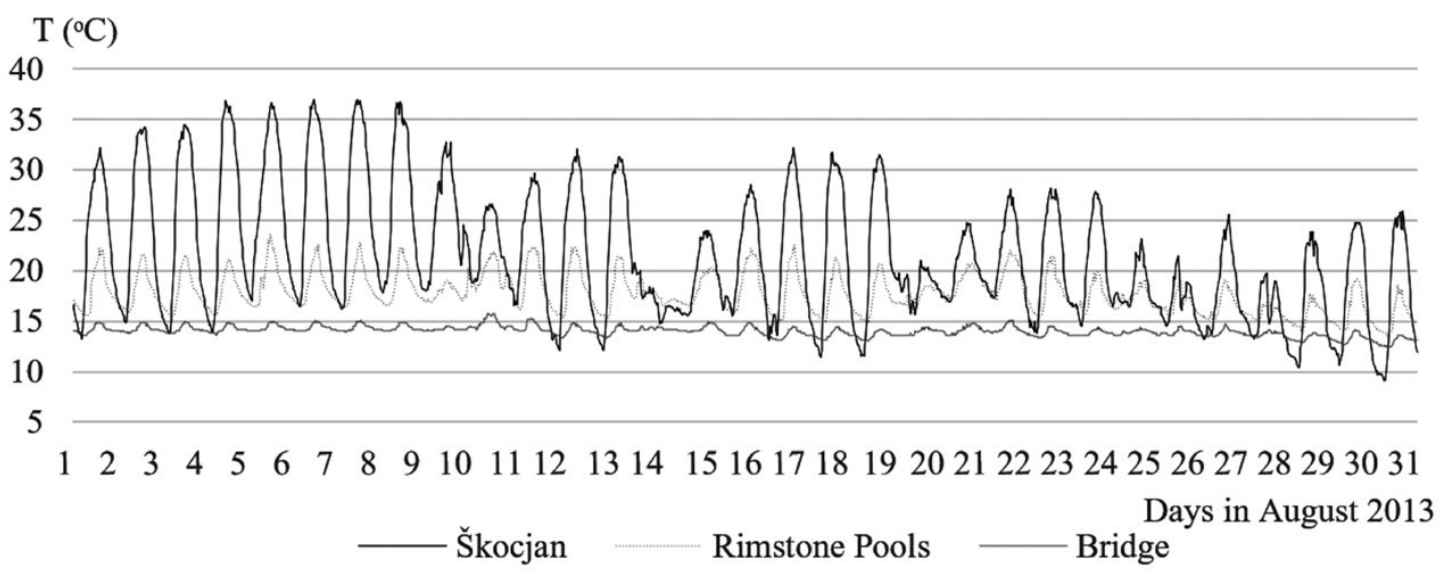

Figure 15: Temperature courses for ten days of August 2013 at the Bridge, Rimstone Pools and in the outer environment in the village of Škocjan. The outer air data were obtained at 30-min intervals.

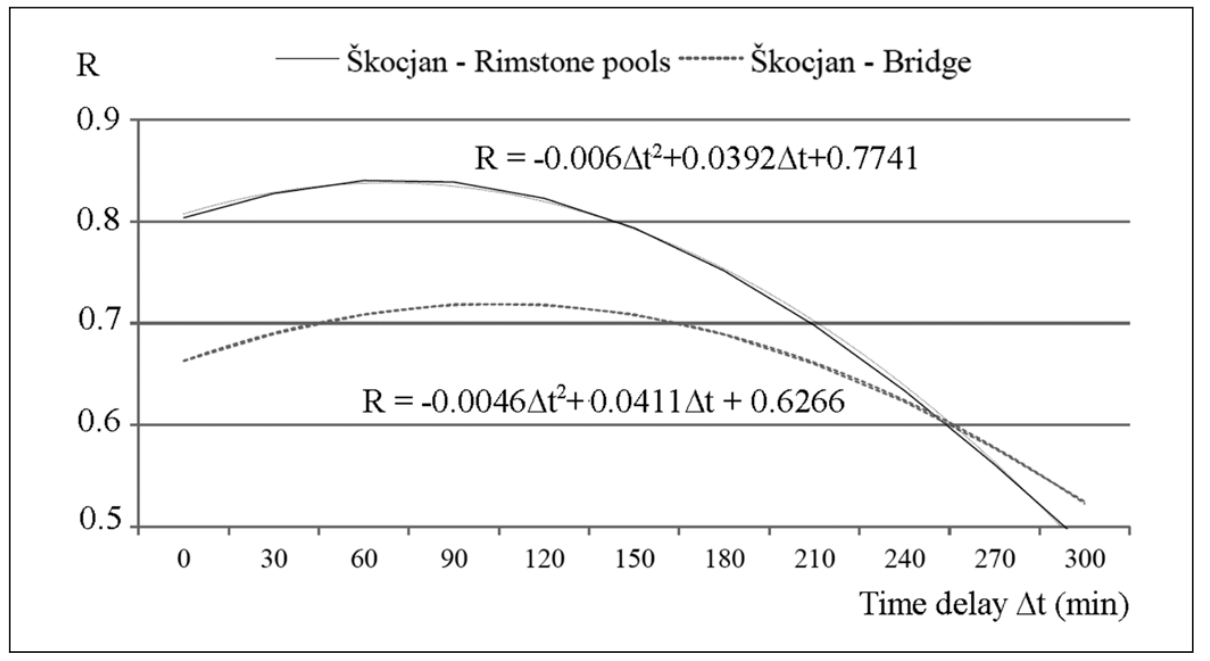

Figure 16: Correlation coefficients $R(\Delta t)$ according to different time lags $\Delta t$ between the temperature data sets for August 2013 at the outer measuring site in Škocjan and at measuring sites at the Rimstone Pools (Ponvice) - upper curve and the Bridge (Most) - lower curve. Both curves are also fitted by a polynomial function - dashed lines. The total length of the data sets is 732.5 hours (30.5 days). 
$R(n \Delta t)$ of the cross-correlation coefficients between the pairs of time series of data, in which one set is time-delayed for different $\Delta t$ (see e.g., Essenwanger, 1986). We can compare the pairs of time series data at locations A and $B$ in the following way:

$$
\begin{aligned}
& \mathrm{T}(\mathrm{A}, \mathrm{t} 1 \rightarrow \mathrm{t} 2): \mathrm{T}(\mathrm{B}, \mathrm{t} 1 \rightarrow \mathrm{t} 2) \\
& \mathrm{T}(\mathrm{A}, \mathrm{t} 1 \rightarrow \mathrm{t} 2): \mathrm{T}(\mathrm{B}, \mathrm{t} 1+\Delta \mathrm{t} \rightarrow \mathrm{t} 2+\Delta \mathrm{t}) \\
& \mathrm{T}(\mathrm{A}, \mathrm{t} 1 \rightarrow \mathrm{t} 2): \mathrm{T}(\mathrm{B}, \mathrm{t} 1+2 \Delta \mathrm{t} \rightarrow \mathrm{t} 2+2 \Delta \mathrm{t}) \\
& \mathrm{T}(\mathrm{A}, \mathrm{t} 1 \rightarrow \mathrm{t} 2): \mathrm{T}(\mathrm{B}, \mathrm{t} 1+3 \Delta \mathrm{t} \rightarrow \mathrm{t} 2+3 \Delta \mathrm{t})
\end{aligned}
$$

$\mathrm{T}(\mathrm{A}, \mathrm{t} 1 \rightarrow \mathrm{t} 2): \mathrm{T}(\mathrm{B}, \mathrm{t} 1+\mathrm{n} \Delta \mathrm{t} \rightarrow \mathrm{t} 2+\mathrm{n} \Delta \mathrm{t})$.

In this way that $\mathrm{n}+1$ correlation coefficients $R(n \Delta t)$, $\mathrm{n}=1, \ldots \mathrm{n}+1$ can be calculated for $\mathrm{n}+1$ different time shifts $0, \Delta t, 2 \Delta t, 3 \Delta t, \ldots$ between the pairs of time series. The highest value of $R$ is an estimate for the time lag between the two sets of data as a whole. The results of this are shown in Fig. 16. The calculated time lag from Škocjan to the Rimstone Pools is 98 minutes - about $1 \frac{1}{2}$ hour, and from Škocjan to the Bridge 134 minutes - about 21/4 hours.

\section{DISCUSSION}

The natural conditions of closed caves are constant and governed by the equilibrium between the cave air and cave walls, while in partly open caves there are exchanges of air with the outer environment, and thus the conditions are prone to outer variations. The natural conditions in tourist caves are often disturbed by visits, and they may recover if the time between the visits is long enough. Such disturbances must be considered in the management of tourist caves (Song, 2000; Fernández Cortés, 2004; Linhua, 2000; Liñán et al., 2008), and the return to natural conditions should be ensured, as otherwise the microclimate might be affected by irreversible changes that can damage cave phenomena, such as the growth of speleothems. It is reasonable to assume that the time after the last daily visit and during the night could be such a recovery time period, and that the natural conditions could be regained in night and morning hours.

\section{ON THE FINDINGS FOR THE CLOSED PART OF THE CAVE}

\section{The closed location at Calvary}

The location at Calvary is more or less that of a closed cave, except when the doors are opened, which occurs when visitors enter the cave through the artificial tunnel from the outer environment at Globočak. Therefore, Calvary is only temporarily "not closed" (Gams, 2002; Grgič, 2014).

The average October 2016 temperature at Calvary was around $12.2{ }^{\circ} \mathrm{C}$ and the $\mathrm{CO}_{2}$ concentration around $1600 \mathrm{ppm}$. The temperature and the $\mathrm{CO}_{2}$ concentration fluctuations were stronger and more frequent with a greater number of visitors and more visits per day (Figs. 7 a to $\mathrm{d}$ ), as is clearly evident in the monthly averaged daily courses of both variables (Fig. 8). In addition to eventual anthropogenic influences, Calvary may also be subjected to the intrusion of warmer outer air through the opened tunnel in the warm part of the year or on warm days. This causes a rise in temperature and a decrease in $\mathrm{CO}_{2}$ concentration, which is clearly observed at Calvary. When the outside is cold, updraught chimney effect brings air from deeper parts of the cave to Calvary. In that case the temperature there again rises, though somewhat less, as deeper in a cave it is not as warm as it is outside on warm days, while the $\mathrm{CO}_{2}$ concentrations on colder days show only weak fluctuations directly connected to visits.

As the temperature at Calvary stays around $12{ }^{\circ} \mathrm{C}$ all the time, it is the outer air temperature that determines whether there will be an airflow or not. Unfortunately, in 2016 there were no temperature measurements at the tunnel entrance at Globočak, in a sinkhole some $70 \mathrm{~m}$ below the Škocjan plateau. So there is no reliable temperature data close to the entrance of the tunnel that can be used to distinguish between the updraught and downdraught chimney effects. However, in such concave terrain shapes as Globočak the temperature inversions form rather regularly during evenings and nights. So most likely in the mornings and late evenings the temperature there is lower than in Škocjan plateau, but we do not know exactly how much lower. As such, the temperature differences between the cave and the surface cannot be used as a criterion when considering the direction of the chimney effect. We could only speculate that in the afternoons of warm days it is most probably warmer on the outer side of the entrance to the tunnel, and thus causing the downwards chimney effect when the doors open.

Some additional information could be inferred looking at the two separate cases of warm and cold days (Figs. 9 and 10).

On the first of the warm days (Fig. 9, Oct 24) the $\mathrm{CO}_{2}$ concentration did not decrease at any of the visits, as this day was not so warm as the next two days, and perhaps due to there being no intrusions of air from outside. After the first day's early afternoon visit, with 64 visitors, 
the $\mathrm{CO}_{2}$ concentration increased by around $1000 \mathrm{ppm}$. On the second day (Oct 25) there was a relatively strong decrease in $\mathrm{CO}_{2}$ at the early afternoon and for the afternoon visit, down by almost $2000 \mathrm{ppm}$, although there were only 24 and 23 visitors on these two visits, with a quick return up to the previous level. On the third of the warm days (Oct 26) the number of visitors in the early afternoon was greater, with 92 people, and there was a decrease in the $\mathrm{CO}_{2}$ concentration only for the morning visit, followed by quick increase.

On colder days (Fig. 10) there were only some small decreases in $\mathrm{CO}_{2}$ concentration, raising the questions of whether no downdraughts occurred at all and only updraughts happen. This is observed especially on the first day (Oct 9) with three decreases of about $400 \mathrm{ppm}$ after each of the visits, with 190, 136 and 101 visitors. This slow but steady decrease during the whole three days, which certainly could not be due to anthropogenic emissions, is very evident.

\section{The effects of airflow vs. anthropogenic emissions}

Based only on the analysed temperature and concentration data it is not possible to give some firm judgment on the relative importance of airflow vs. emissions, but some estimates can still be done.

How strong could the intrusions of outside air through the tunnel be? If we look at, for example, an early afternoon visit in October at around 13:00 (Fig. 8), we see that on a monthly average the $\mathrm{CO}_{2}$ concentration at Calvary first decreases rapidly from about $1600 \mathrm{ppm}$ to about $1590 \mathrm{ppm}$ - down by about $10 \mathrm{ppm}$. With the total volume of Calvary being around $44,000 \mathrm{~m}^{3}$ (Drole, 2013) such a reduction by mixing would require an additional $375 \mathrm{~m}^{3}$ of air from the outside with around 400 ppm $\mathrm{CO}_{2}$. This would be possible by airflow through a tunnel lasting five minutes at a speed of only a few tenths of a m/s which is realistic. Most likely this $375 \mathrm{~m}^{3}$ is the upper limit, as it assumes mixing of outside air with all the air in this part of the cave.

The $\mathrm{CO}_{2}$ concentration then rapidly over just five minutes increases again to $1600 \mathrm{ppm}$, and then during the following half an hour to about $1640 \mathrm{ppm}$, i.e., in total by about $50 \mathrm{ppm}$. For a volume of $44000 \mathrm{~m}^{3}$, this means $22 \mathrm{~m}^{3}$ of $\mathrm{CO}_{2}$ or about $11 \mathrm{~kg}$ of $\mathrm{CO}_{2}$. Moreover, this estimate also assumes anthropogenic emissions into the entire volume of this part of the cave. The breathing of 100 people at moderate effort would emit about $4.5 \mathrm{~kg}$ of $\mathrm{CO}_{2}$ in 15 minutes. Since the average visit in October at noon is a little over 100 visitors, it is most likely that the increase in concentration by more than twice as much may be partly due to the stronger breathing of visitors and partly due to other reasons.

While this is more a guess than a firm judgment, we can say that even in the small cave volume at Calvary, where in general emissions are more important, the effects of airflow also seem to be rather significant.

\section{The upwards and downwards chimney effects}

Cases of no or airflow could only happen when the cave and outside temperatures are equal, or the difference is very small. How often could that occur? Having no reliable information on temperature at the tunnel entrance at Globočak, the comparison of inner and outer temperatures cannot help to determine this. Moreover, unfortunately no airflow measurements were taken at an appropriate part of the cave during the time we are analysing intis study. Still, later in 2018 wind measurements were introduced in some Karst caves as part of the joint project of Škocjan Caves Park, the Karst Research Institute ZRC SAZU and MEIS d.o.o (Mlakar et al., 2020). They kindly provided us with the airflow data measured at 10-minute time intervals at Labyrinth in a passage between the Silent and Murmuring Caves for October 2018 to 2020. We used only the 2018 and 2019 data, as visits in 2020 were very rare and irregular due to the covid-19 pandemic. In the hope that these Octobers are also representative for "our" October 2016, we analysed the data, which show some very light and regular airflows. Taking the maximum air velocity $\mathrm{v}_{\max }$ during the 10 -minute measuring time interval as a criterion, two thirds of the measurements registered the non-zero $\mathrm{v}_{\max }$. With a threshold of $0.3 \mathrm{~m} / \mathrm{s}$ a total of $1.3 \%$ of all measurements show such a stronger breeze. Choosing only the cases close to the times of visits, we found that half of these stronger airflows were in the one-hour time periods around visits, which covers $12.5 \%$ of all measuring time intervals (the other half occur at other times). Taking the $\pm 25^{\circ}$ range around the main upwards and downwards directions, we get 19 cases upwards, mostly for morning and early afternoon visits, and 34 downdraught cases, almost all for afternoon visits, and only two at morning visits. In around $4 \%$ of time intervals around visits there are downdraughts or updraughts, with $\mathrm{v}_{\max }$ exceeding 0.3 $\mathrm{m} / \mathrm{s}$ in a 10 -minute time interval.

\section{The recovery of change fluctuations in $\mathrm{T}$ and $\mathrm{CO}_{2}$ back towards the natural conditions}

During the day each change fluctuation is impacted by the next visit. After the last visit of the day, the temperature decreases steadily and slowly back to the constant value in the late night/early morning, when it stabilizes at the what could be considered as close to the natural temperature of the cave in a condition of air-walls balance. From the analysis of temperature data, it was found that at Calvary (see Fig. 8) from approx. 03:00 until the morning the temperature stays rather constant. Thus, the 
average temperature between 02:00 and 07:00 is a good estimate for natural temperature there. The temperature time series (Fig. 12) shows, that the characteristic time for the exponential decrease of the temperature change fluctuations at Calvary is around 4 hours in October.

The decrease of the change in $\mathrm{CO}_{2}$ concentration takes longer and is also less reliable. The decrease in $\mathrm{CO}_{2}$ concentration is slow and does not stabilize at a constant value before the first morning visit, so the natural value of the $\mathrm{CO}_{2}$ concentration cannot be obtained directly from the data and can only be roughly estimated.

The explanation of the recovery of the microclimate to natural conditions is reliable to a certain extent only when it is evident from the data. For example, in January the impact of visits at Calvary is extremely low (see Table 1) for several reasons, such as there are not many visitors, and thus the doors open for a short time and the stays at each location is are rather short, and these are some of the reasons why in January the temperature change fluctuations $\Delta T$ at Calvary that occur due to visits are very small.

Table 1: An overview of the average monthly number of visitors $N$, of average monthly temperature $T_{0}$ from 02:00 to 07.00 as an estimate for natural $T_{\text {nat }}$, the increase $\Delta T=T-T_{0}$ at 16:00 (March), at 16:30 (October) and at 18.00 (June) and the estimates for characteristic times $\tau_{T}$ at Calvary for 8-hour long time periods starting from those times.

\begin{tabular}{|l|c|c|c|c|}
\hline month & $\mathrm{N}$ (visitors/day) & $\mathrm{T}_{0}\left({ }^{\circ} \mathrm{C}\right)$ & $\Delta \mathrm{T}\left({ }^{\circ} \mathrm{C}\right)$ & $\tau_{T}$ (hours) \\
\hline January & 56 & 12.04 & $<0.01$ & - \\
\hline March & 186 & 12.00 & 0.06 & 3 \\
\hline June & 455 & 12.10 & 0.08 & 3.6 \\
\hline October & 289 & 12.19 & 0.04 & 3.8 \\
\hline
\end{tabular}

The characteristic time for the exponential decrease of the temperature change fluctuations back to natural conditions, which happens in 3 to 4 hours, should be extended up to about 6 hours if also considering various uncertainties, as explained in the Results section. There it was also explained that this characteristic time does not depend on the magnitude of the change fluctuation in the temperature, which can also be seen on this table.

\section{The overall air-walls heat exchange coefficient}

It takes some time for heat disturbance to spread throughout the whole cave. We thus start our analysis of the characteristic time only after 1.5 hours after the last visit of the day, believing that 1.5 hours is long enough to achieve an approximate homogeneity over the cave. Such spreading also causes the differences between the air temperature $T$ and the wall temperature $T_{w}$ at the walls of the cave, leading to heat exchange between the air and walls. There is a thin laminar layer in the air right next to the wall, the walls may be covered with a thin layer of water, there may be some cracks in walls, etc., all of which influences the efficiency of the exchange. Therefore, the total, overall exchange coefficient $h_{\mathrm{T}}$ is a combination of individual exchange coefficients for each of these sublayers. During the exchange, the air-wall temperature differences decrease, so the air temperature changes exponentially with time, and the characteristic time $\tau_{T}$ of this exponential time course is inversely proportional to the exchange coefficient $h_{T}: \tau_{T}=\frac{V c_{p}}{h_{T} A}$, for which according to the first part of the paper (Rakovec, 2020), a round value of $1 \mathrm{Wm}^{-2} \mathrm{~K}^{-1}$ was taken for simplicity, which will then be checked according to the data. Similar reasoning holds for the $\mathrm{CO}_{2}$ exchange.

With a rough estimate of the characteristic time $\tau_{T}$ we are also able to check the overall air-walls heat exchange coefficient. The section of the cave around Calvary is $70 \mathrm{~m}$ long, $35 \mathrm{~m}$ wide, and $18 \mathrm{~m}$ high (Drole, 2013), and thus its volume $V$ is around $44000 \mathrm{~m}^{3}$ The area $A$ of the walls, that are partly opened on the lower side, is around $8000 \mathrm{~m}^{2}$, therefore the ratio $V / A$ is around $5.5 \mathrm{~m}$. Using the rough estimate of $1 \mathrm{Wm}^{-2} \mathrm{~K}^{-1}$ we would get $\tau_{T}=90 \mathrm{~min}$. As our characteristic times are much longer, the effective overall transfer coefficients at Calvary are obviously lower than 1 $\mathrm{Wm}^{-2} \mathrm{~K}^{-1}$. For example, for $\tau_{T}=3$ hours the value is $h_{\mathrm{T}}=$ $0.52 \mathrm{Wm}^{-2} \mathrm{~K}^{-1}$ and for $\tau_{T}=6$ hours the value is $h_{\mathrm{T}}=0.26$ $\mathrm{Wm}^{-2} \mathrm{~K}^{-1}$. The argument presented by Rakovec (2020) that for $\mathrm{CO}_{2}$ the characteristic time should be longer, $\tau_{\mathrm{CO}_{2}}$, is also supported by the data - e.g., compare a slower decrease for $\mathrm{CO}_{2}$ in Fig. 13 with $\tau_{\mathrm{CO} 2}=7$ hours, with the faster one in Fig. 12 with $\tau_{T} 4$ hours.

\section{The noisy fluctuations and changes at Tent and at Passage}

The monthly average October 2016 temperatures at Tent and Passage, being at approx. the same elevation in the cave, are around $12.3{ }^{\circ} \mathrm{C}$ and $13.2{ }^{\circ} \mathrm{C}$, respectively. So Tent is roughly as warm as Calvary, while Passage is about one degree warmer. The $\mathrm{CO}_{2}$ concentration at tent is between 1900 and 2000 ppm - higher than at Calvary, while at Passage it is much lower - between 800 and 900 ppm only.

When looking at individual days for Tent, it turned out that there are many temperature variations at this location (Fig. 7b, similar to Passage), and this is "random noise", so monthly averages are needed. This noise is probably due to draughts and pauses between draughts. Temperature change fluctuations connected to visits can be detected only after monthly averaging (Figs. 11 and 12), but still some continuous noise is present. As regards $\mathrm{CO}_{2}$, the daily courses show almost no noise. It is interesting that the change fluctuations at the times of visits are in the op- 
posite direction at the two locations: at Tent they are positive, with a rising temperature for a short time, and at Passage they are negative, reducing it. The change fluctuations in the $\mathrm{CO}_{2}$ concentrations go in opposite ways.

A possible explanation for the continual noisy variations of temperature at Tent for $\approx \pm 0.2{ }^{\circ} \mathrm{C}$ degrees, and at Passage, being evident even after averaging over the whole month - as seen in Figs. 14 and 15 could be the airflow gusts and lulls that these two locations experience all the time. These could be from the outer environment, from other parts of the cave, through some fractures, etc. The decrease in $\mathrm{CO}_{2}$ concentration during the night at both locations (Figs. 11 and 12) could be in favour of continual mixing with the outer air, where the concentration is much lower than in the caves. In particular the very low concentration at Passage, being only half that at Calvary, supports such an assumption.

Earlier we have shown that downdraughts occur in Silent Cave more frequently than updraughts, so in monthly averaging the downdraught effects might prevail. At the times of visits, the temperature at Passage decreases by about $-0.15{ }^{\circ} \mathrm{C}$ (Fig. 12). If that is the result of the downdraught chimney effect, the air to Passage is from the direction of Tent, which is about $1{ }^{\circ} \mathrm{C}$ colder than Passage - thus cooling occurs at Passage. Positive perturbances at Tent of about $+0.15{ }^{\circ} \mathrm{C}$ (Fig. 11) could again be the result of a downdraught from Calvary, in spite of the fact that at Calvary the temperature is similar to a Tent. As Calvary is $40 \mathrm{~m}$ higher than Tent, the adiabatic compression during the descent of air should be considered (this is not necessary for Tent and Passage, as these two locations are on a similar elevation, only 10 $\mathrm{m}$ difference). In descent, the air adiabatically compresses which results in adiabatic warming of $1 \mathrm{~K}$ per every $100 \mathrm{~m}$ of descent (and with ascending the opposite cooling occurs). The air arriving from Calvary down to Tent would warm up purely adiabatically by $0.4^{\circ} \mathrm{C}$. There are several possible reasons for the positive temperature perturbation at Tent being smaller: the decrease is not purely adiabatic, or the air does not originate just from Calvary, but from some lower location closer to Tent, or perhaps both reasons are valid.

The continuous decrease in the $\mathrm{CO}_{2}$ concentration during the night could be due to noisy mixing, at least partly with the outer air, while at the times of visits it could be the downdraughts that again might explain the negative change fluctuations at Tent in the $\mathrm{CO}_{2}$ concentration, if the downdraught transports the air from Calvary (with a concentration around $1600 \mathrm{ppm}$ ) to Tent (around $1900 \mathrm{ppm}$ ), while positive fluctuation would occur with the air moving from Tent to Passage (with a concentration below $1000 \mathrm{ppm}$ ).

Monthly averaged data show that temperatures at
Tent, the lowest measuring location in Silent Cave, and at Passage, before entering the Murmuring Cave, do not stabilize in the early morning hours at some constant value (Figs. 11 and 12). The reasons for this are still unknown, though we can suspect some draughts could be present through side channels, cracks, etc. that cause continued air exchanges.

\section{ON THE FINDINGS FOR THE NON-CLOSED AND LARGE MURMURING CAVE}

The Murmuring Cave is a wide open cave. There is clear evidence that outer air variations prevail and hardly any direct impact of visits can be observed there, and the data show almost no change fluctuations connected with them. The reduction in the outer temperature variations is evident from a graphical presentation of the temperature time series (Fig. 15) without any additional analysis, and the variations and roughly only half those at the Rimstone Polls and one-tenth those at Bridge.

The influence of the outer air in this rather open part of the cave system has been more thoroughly analysed by considering the pairs of time series of data at the outer location at Škocjan and the two inner ones. The time series on temperatures were compared, using several time lags for the inner time series and shifted in time for one $\Delta t$, for two $\Delta t$, three $\Delta t, \ldots$ etc. The correlation coefficients $\mathrm{R}$ are calculated for all different time lags applied on the inner time series and the highest similarity between the outer time series with the outer one was determined from the $R(\Delta t)$ curve (Fig. 16). The phase shift in August 2013 from Škocjan to the Rimstone Pools is 98 minutes, about $1^{1 / 2}$ hour, and from Škocjan to the Bridge deeper in the cave 134 minutes, about $2 \frac{1}{4}$ hours.

Once having estimates on amplitudes and phase shifts, one could try to look for more information. If diffusion would be the prevailing process leading to a decrease in the amplitude and to phase shift, from the diffusion equation it follows that the amplitude would decrease with the distance $x$ as $e^{-x \sqrt{\frac{\omega}{2 D_{T}}}}$, while the phase shift would be $t(x)=\frac{x}{\sqrt{2 \omega D_{T}}}$. Here $\omega$ represents the frequency of the prevailing variations, in our case the $\omega$ for daily variations is $\omega=2 \pi / 24 \mathrm{~h}$, and $D_{T}$ stands for the effective heat diffusivity (for details consider e.g., Rakovec 2020). As locations at the Rimstone Pools and Bridge are both in the cave and thus in a similar environment, considering the diffusion between them as one of the processes of exchange might be appropriate. A rough estimate of the distance between the locations is $200 \mathrm{~m}$, the ratio between the amplitudes around 1/10, and the phase shift around' $\Upsilon$ hour. Using this data in the diffusion equation, from the comparison of the amplitudes $D_{T}$ would be below $1 \mathrm{~m}^{2} \mathrm{~s}^{-1}$, and from the comparison of the 
phase shift over $30 \mathrm{~m}^{2} \mathrm{~s}^{-1}$. The two estimates essentially differ, indicating that diffusion is not the prevailing process of exchanges between the two locations; there are also advection, buoyancy drive flows, etc. So no value could be inferred from them, and perhaps only a rough hint as to the order of magnitude: $D_{T} 10 \mathrm{~m}^{2} \mathrm{~s}^{-1}$.

\section{CONCLUSIONS}

The data on temperature $\mathrm{T}$ and on $\mathrm{CO}_{2}$ concentration $\mathrm{c}_{\mathrm{CO} 2}$ measured in 2016 were analysed for three locations in the Silent Cave: at Calvary, the uppermost location in the Silent Cave, close to the entrance tunnel, at Tent, lower in the Silent Cave, and at Passage, a location at approximately the same elevation as Tent, but closer to the wide open Murmuring Cave.

October 2016 was studied in more detail, as in that month there were only three visits per day, but with enough visitors to cause change fluctuations that could be clearly connected with the visits. On average in October Passage is the warmest (around $13.2{ }^{\circ} \mathrm{C}$ ) and the $\mathrm{CO}_{2}$ concentration is the lowest (around $800 \mathrm{ppm}$ ), Tent and Calvary are colder (around $12.3{ }^{\circ} \mathrm{C}$ ) and the $\mathrm{CO}_{2}$ concentration is the highest at Tent the highest (around $1900 \mathrm{ppm}$ ) and somewhat lower at Calvary (around 1600 $\mathrm{ppm}$ ). There are a lot of change fluctuations and variations around these average conditions.

At Calvary change fluctuations at the times of visits are evident even on each of the individual days. They are stronger when there are more visitors; for example, in June with a hundred or several hundred visitors per visit the temperature change fluctuations on visits reach around $0.5{ }^{\circ} \mathrm{C}$, and the change fluctuation are weaker when the number of visitors is smaller, such as in January with only around ten visitors per visit, reaching only $0.1{ }^{\circ} \mathrm{C}$.

At the two other locations, lower in the Silent Cave, the continual, noisy variations of $\mathrm{T}$ and of $\mathrm{c}_{\mathrm{CO} 2}$ are much stronger, so that the signal on change fluctuations at the times of visits to the cave only becomes evident after monthly averaging of the daily courses of $\mathrm{T}$ and $\mathrm{c}_{\mathrm{CO} 2}$. Such noisy variations can be caused by random fluctuations in air movements e.g., by gusts of wind in a light breeze.

On the warmer days of October 2016, the $\mathrm{CO}_{2}$ concentration drops significantly at Calvary at the times of visits, while on the colder days it does not. That could be a clue to the intrusion of the outer air through the opened tunnel doors and the fact that the outside $\mathrm{CO}_{2}$ concentration is several times lower than the one in a cave.

The airflow direction data, measured later (Octobers from 2018 on) show that some light air movement is rather regular, while somewhat stronger breezes appear at the times of visits. Due to the warm outer air during late afternoons these are almost all downdraughts (around $2 / 3$ of the total), while the updraughts (around 1/3) happen more frequently in the earlier, colder part of the day.

Prevailing downdraughts could explain at first glance the surprising behaviour of temperature and $\mathrm{CO}_{2}$ change fluctuations at the times of visits at Tent and Passage. For temperature these changes are positive at Tent and negative at Passage. For $\mathrm{CO}_{2}$ these changes are negative (and less expressed) at Tent, and clearly positive at Passage. If the prevailing downdraughts are the cause of these effects, that means that air from direction of Calvary descends at Tent and this air also partly adiabatically warms during the descent, while at Passage the air comes from the colder Tent. Similar results are found for $\mathrm{CO}_{2}$ : at Tent the air comes from the direction of Calvary, where the concentration is somewhat lower (and thus the decrease in concentration is weaker), while the air from Tent arrives at Passage, where the concentration is twice as high as at Passage (and thus there are clear upwards $\mathrm{CO}_{2}$ change fluctuations).

The return of the perturbed conditions towards the undisturbed natural conditions overnight after the last visit of a day is exponential. The characteristic time of such a decrease was studied for Calvary, which is an almost closed part of the cave, when the entrance tunnel doors are closed. For temperature, this characteristic time $\tau_{T}$ which indicates the time in which the perturbation diminishes to $1 / \mathrm{e} \approx 0.37$, is around 4 hours. Taking into account the uncertainties connected with this estimate, the value might be also somewhat high - perhaps up to 6 hours. For $\mathrm{CO}_{2}$ the estimate is less certain, mostly due to the fact that the concentration does not stabilize at some constant value during the night. But it is still clear from the results that the $\mathrm{CO}_{2}$ decrease in the change fluctuations is approximately twice as slow - meaning that the heat exchange between the cave air and walls is more effective than the gas exchange.

In the Murmuring Cave that is wide open to the outside, the bigger volume and the exchanges with outside air mean that the effects of visits on temperature and $\mathrm{CO}_{2}$ are negligible. On the basis of data from 2013 it was possible to estimate the diminishing amplitudes of the effects of the outer environment's daily variations in the cave, as well as the longer time shift (phase delay) deeper into the cave. The amplitude of daily variations in temperature at 
the Bridge is on average only half that seen at Škocjan on the plateau above the cave, while deeper in the cave, at Rimstone Pools, the amplitude is only one-tenth that outside. The time shift to Rimstone Polls is about $1 \frac{112}{2}$ hours and to the Bridge $2 \frac{1 / 4}{4}$ hours.

Once we have the estimate of the characteristic times of the exponential decrease in the change fluctuations over time, a rough estimate of the overall heat exchange between air and walls can be obtained. For temperature (in fact - for heat) the formula is $\tau_{T}=\frac{V c_{p}}{h_{T} A}$, which follows from the idea that after the heat change fluctuations spread and have eventually reached all over the whole volume of the cave, the cave's walls are the final heat sink. From the measured data an estimate can be obtained for $h_{\mathrm{T}} \approx 0.25$ to $0.5 \mathrm{Wm}^{-2} \mathrm{~K}^{-1}$. Similarly, but only with a very rough order of magnitude, heat diffusivity $D_{T}$ can also be evaluated, and is found to be of the order of magnitude $D_{T} \sim 10 \mathrm{~m}^{2} \mathrm{~s}^{-1}$.

The tourism management of Škocjan Caves should take into consideration the main features of the cave system. In the open Murmuring Cave, where the impacts of visits are negligible, management should be focused on the physical aspects of the visit regarding the safety of visitors and protection of speleothems and infrastructure. In the Silent Cave the greater impacts of visits, as confirmed by the data call for more monitoring of the microclimate. The fact that the outer air plays an important role in the natural balance of conditions in Silent Cave means there is a need for continuous monitoring of the microclimate, including the airflows, in order to detect important changes in a timely manner.

Intrusions of outside air through the entrance tunnel are, of course, due to the opening of the doors. These intrusions have different consequences in terms of temperature depending on the time of year. In terms of $\mathrm{CO}_{2}$, however, they always cause outside air to move to Calvary with much less $\mathrm{CO}_{2}$. This seems to at least partly contribute to the fact that Calvary's $\mathrm{CO}_{2}$ concentration is lower throughout the year than, for example at Tent, and this difference is not very great in winter (about 100-200 $\mathrm{ppm})$, but bigger in summer, when such intrusions are more frequent and pronounced, due to the more visits and visitors, with a difference of up to $500 \mathrm{ppm}$.

If the intrusions of outside air into Calvary are found damaging to the cave then they should be prevented or at least mitigated. It is inconvenient for visitors to come to Calvary from Passage and then return back the same way, and that is why there is an artificial tunnel from Globočak. A partial reduction in intrusions could be achieved by visitors waiting in the tunnel in front of the closed inner door until the outer door is closed. Of course, with a larger number of visitors in a narrow tunnel the temperature, humidity and $\mathrm{CO}_{2}$ concentration would increase, with environmental consequences that could include growth of algae spreading forward across the cave. Therefore, the effects of outside air intrusions, which are observed throughout the Silent Cave, especially in the warm half of the year, still need to be carefully studied from the point of view of cave protection.

Though the regeneration time for temperature is known and suggests that change fluctuations calm down during the night, there are also the times when the temperature is higher due to more visits and visitors. As such, if visits are very frequent, without enough time between them, then the increase in temperature can persist for a greater part of the day.

The characteristic time of descent $\tau_{T}$ to the natural values is a useful tool for the management of visits. The microclimate protection measures for the cave should include limiting the size of the groups entering the caves, while the scheduled visiting times should take into account the appropriate time span between visits.

In order to assess the changes in the caves' microclimates, it would be appropriate to also measure the calcite depositions at several measuring points at certain $\mathrm{CO}_{2}$ concentrations and temperatures.

The findings presented in this study imply the need for continuous monitoring of the Škocjan Caves' microclimate, further research on the $\mathrm{CO}_{2}$ concentration and more reliable estimate of the regeneration characteristic time $\tau_{\mathrm{CO} 2}$. Such monitoring should not be only focused on the changes that occur at the measuring stations, but designed in such a way as to track changes in the system as a whole.

\section{ACKNOWLEDGMENTS}

Thanks to the Public Service Agency Škocjan Caves Park, which has enabled the monitoring of the microclimate and use of the Škocjan Caves maps, and to MEIS d.o.o, the Karst Research Institute ZRC SAZU, and Škocjan Caves Park that have kindly shared the wind measure- ments data, to F. Drole from the Karst Research Institute for the data on the sites of Škocjan Caves. We also highly appreciate the valuable comments of both reviewers that greatly contributed to the quality of the paper. 


\section{REFERENCES}

Almemo 1, 2020: Thermo-anemometer FVA935-TH5K2 Alhborn Almemo.- [Online] Available from: http:// www.logingel.com/1004/182750/0/ShowProduct/ Hot-wire_air_speed_probe [accessed 16th December 2020].

Almemo 2, 2020: FYA600-CO $\mathrm{CO}_{2}$ Ahlborn Almemo. [Online] Available from: www.ahlborn.com/download/ pdfs/kap16/eng/CO2f1e.pdf [accessed 11th March 2019].

ARSO 2019: Meteorological station of Škocjan.- [Online] Available from Agency of Republic Slovenija for environment: http://meteo.arso.gov.si/met/sl/archive/ [accessed 11th February 2019].

Badino, G., 1995: Fisica del clima sotterraneo. - Memorie dell'istituto italiano di speleologia 7, serie II, Bologna, pp. 136, Bologna.

Bella, P., 2002: Cave environment geo ecology: spatial structure, time-spatial changes and stability of cave geosystems. - In: Carrasco, F. et al. (eds.) Karst and Environment. pp. 395-400, Nerja, Malaga.

Bourges, F., Genthon, P., Genty, D., Lorblanchet, M., Mauduit, E. \& D. D'Hilst, 2014: Conservation of prehistoric caves and stability of their inner climate: Lessons from Chauvet and other French caves.- Science of the Total Environment 493, 79 - 91. https:// doi.org/10.1016/j.scitotenv.2014.05.137

Calaforra, J. M., Fernández-Cortés, A., Sánchez-Martos, F., Gisber, J. \& A. Pulido-Bosch, 2003: Environmental control for determining human impact and permanent visitor capacity in potential show cave before tourist use.- Environmental Conservation 30 (2), 160 - 167. https://doi.org/10.1017/ S0376892903000146

Cañaveras, J.C. \& S. Sánchez - Moral, 2002: Impacto ambiental del hombre en las cuevas.- In: Carrasco F., Durán J. J., Andreo B. (eds.) Karst and Environment., pp. 499-504, Malaga.

Castellani, V., Sala, S. \& D. Piteam, 2007: A new method for tourism carrying capacity assessment. - WII Transaction on Ecology and the Environment, Vol. 106, 365 - 374 .

Ceballos-Lascuráin, H., 1996. Tourism, ecotourism and protected areas: The state of nature-based tourism around the world and guidelines for its development.IUCN, xiv, pp. 301, Gland, Switzerland. https://doi. org/10.2305/IUCN.CH.1996.7.en

Cuevas-Gonzales, J., Fernandez-Cortıs, A., MupozCervera, M.C., Andreu, J. M. \& J.C. Capaveras, 2010: Influence of Daily Visiting Regime in Tourist Cave at Different Seasons. - In: Bartolomé. A., Carrasco,
F., Durán, J.J. \& J. W. LaMoreaux (eds.) Advances in Research in Karst Media. Springer, pp. 475 - 481.

Cigna, A., 2002: Modern trend in cave monitoring. - Acta carsologica, 31, 1, 35-54. https://doi.org/10.3986/ ac.v31i1.402

Cigna, A., 2004: Climate of Cave. - In: Gunn, J. (ed.) Encyclopedia of caves and karst science. Fitzroy Dearborn, pp. 228-230, London.

Debevec, A., 2004: The Škocjan Caves.- Park Škocjanske jame, pp. 44, Škocjan.

Debevec, V., 2004: Speleotherapy.- In: Gunn, J. (ed.) Encyclopedia of Caves and Karst Science. Fitzroy Dearborn, pp. 697 - 699, New York

Debevec, V., Peric, B., Šturm, S., Zorman, T., \& P. Jovanovič, 2017: Škocjan Caves, Slovenia: an integrative approach to the management of a World Heritage Site. In: Parise, M. et al. (eds) Advances in Karst Research: Theory, Fieldwork and Applications. Geological Society of London, Volume 466, pp. 411429, London.

De Freitas, C. R., 2010: The role and importance of cave microclimate in the sustainable use and management of show caves.- Acta Carsologica, 39, 3, 477 489. https://doi.org/10.3986/ac.v39i3.77

Drole, F., 2013: Škocjanske jame - Izdelava profilov in izračun volumnov podzemnih prostorov, Climaparks Project.- Inštitut za raziskovanje krasa ZRC SAZU Postojna, 45/81-2/13, pp. 5, Postojna.

Drole, F., 2015: Nove izmere Škocjanskih jam. Interno poročilo.- Inštitut za raziskovanje krasa ZRC SAZU Postojna, 24. 9. 2015, 4, Postojna.

Dreybrodt, W., 2004a: Carbonate minerals: precipitation. In: Gunn, J. (ed.). Encyclopedia of caves and karst science. Fitzroy Dearborn, 2004, pp.187-188, London.

Dreybrodt, W., 2004b. Dissolution: Carbonate rock. In: Gunn J. (ed.). Encyclopedia of caves and karst science. Fitzroy Derborn, pp. 295-298, London.

Eagles, P. F. J., McCool, F. S. \& D. C. Haynes, 2002: Sustainable tourism in protected areas. Guidelines for planning and management.- World Commission on Protected Areas, Best practice protected areas guidelines series No.8, pp. 183, Cambridge.

Essenwanger, O.M., 1986: General climatology. 1B, Elements of statistical analysis.- Amsterdam etc., Elsevier, xvii+ 424 pp, ISBN 0-444-42426-1 (Vol. 1B) 0-444-40734-0

Fernández Cortés, A., 2004: Caracterización microclimatica de cavidades y análisis de la influencia antrópica de su uso turístico,- PhD Thesis. Universidad de Almería, Departamento de Hidrogeología y Química Analítica VI BI de los Directores, pp. 425. 
Farr, T. A. \& J. L. Marion, 2002: The protected area visitors impact management (PAVIM) framework: a simplified process for demarking management decisions.- Journal of sustainable tourism, Vol. 10, No.1, 31-51.

Furey, N.M. \& P. A. Racey, 2016: Conservation Ecology of Cave Bats.- In: Voigt, C. \& Kingston, T. (eds.) Bats in the Anthropocene: Conservation of Bats in a Changing World. Springer, Cham. pp 463-500, https://doi.org/10.1007/978-3-319-25220-9_15

Gams, I., 2002: Vpliv vdiranja zimskega mraza na jamsko okolje.- Proteus 3, 65, 142, 102-111.

Grgic, I., Iskra I., Podkrajšek B. \& V. Debevec Gerjevič, 2014: Measurements of aerosol particles in the Škocjan Caves, Slovenia.- Environmental Science and Pollution Research, 21, 3, 1915-1923. http:// dx.doi.org/10.1007/s11356-013-2080-4

Hall, M. C. \& J. P. Stephen, 2002: The geography of tourism and recreation: Environment, place and space. Second edition.- Routledge, pp. 132 - 157, London and New York.

Hamilton-Smith, E., 2002: Management Assessment in Karst Areas.- Acta carsologica, 31/1, 13 - 20.

Hanwell 1: Thermometer Hanwell, IMC Group Ltd., Rotronic HygroClip, 4000 RHT Temperature and Humidity monitoring, Data sheet. [Online] Available from https://hanwell.com/data-logger/ [accessed 11th March 2019]. In the text (Hanwell 2019)

James, J. M., 2004: Tourist Caves: Air Quality. In: Gunn J. (ed.). Encyclopedia of caves and karst science. Fitzroy Dearborn, pp. 730-731, New York.

Kranjc, A., 2002: Zgodovinski pregled in opis jam.- In: Peric, B. (ed.) Škocjan Caves Park Park Škocjanske jame, pp. 42 - 57, Škocjan.

Kubešova, S., 2001: Bryophyze flora at lamps in public caves in the Moravian Karst (Czech Republic). Acta Museu Moraviae, Scientiae biologicae (Brno), 86, $195-202$.

Luetscher M., Lismonde, B. \& P. Jeannin, 2008: Heat exchanges in the heterothermic zone of a kar,st system:Monlesi cave, Swiss Jura Mountains.- Journal of geophysical research, Vol 113, F02025, https:// doi.org/10.1029/2007JF000892

Linhua S., Xiaoning W. \& L. Fuyuan, 2000: The influence of cave tourism on $\mathrm{CO}_{2}$ and temperature in Baiyun Cave, Hebei, China.- International Journal of Speleology. 29 B, 1, 4, 77-87.

https://doi.org/10.5038/1827-806X.29.1.4

Liñán C., Iñaki Vadillo I. \& F. Carrasco, 2008: Carbon dioxide concentration in air within the Nerja Cave (Malaga, Andalusia, Spain).- International Journal of Speleology 37, 2, 99-106.

https://doi.org/10.5038/1827-806X.37.2.2
Lismonde, B., 2002a: Vent des Ténèbres. - Climatologie du Monde Souterrain 1, CDS Isère, pp. 167, Grenoble.

Lismonde, B., 2002b: Aérologie des System Karstiques.Climatologie du Monde Souterrain 2, CDS Is $\theta$ re, pp. 362, Grenoble.

Lobo, S. H. A., 2015: Tourist carrying capacity of Santana cave (PETAR-SP, Brazil) : A new methos based on a critical atmospheric parameter.- Tourism Management Perspective 16, $67-73$.

https://doi.org/10.1016/j.tmp.2015.07.001

Manning, R. E., 2002: How much is too much? Carrying capacity of National Parks and protected areas.In: Amberger, A. et al.(eds.) Monitoring and management of visitors flows in recreational and protected area. Conference proceedings. Bodenkultur University Vienna, Austria, 306 - 313, Wien.

Mihevc, A., 2001: Speleogeneza Divaškega krasa.- Založba ZRC SAZU, pp. 180, Ljubljana.

Mihevc, A., 2017: Škocjanske jame. - Proteus 79/7, 8, 9, $323-330$.

Mlakar, P., Grašič, B., Božnar, M. Z. \& F. Gabrovšek, 2020: Information system for scientific study of the micrometeorology of Karst Caves - Case of Postojnska jama, Slovenia. -Acta Carsologica 49/2-3, 297 - 310. https://doi.org/10.3986/ac.v49i2-3.7540

Mulec, J. \& G. Kosi, 2009: Lampenflora algae and methods of growth control.- Journal of Cave and Karst Studies, v. 71, no. 2, 109-115.

Peric, B., 2019: Map of Škocjan Caves, https://www.parkskocjanske-jame.si/en/read/the-skocjan-caves/ description-of-the-caves [accessed 13th December 2019]

Pulido-Bosch, A., Martin - Rosales, W., López-Chicano, M., Rodríguez-Navarro, C.M. \& A. Vallejos, 1997: Human impact in a tourist karstic cave (Aracena, Spain).- Environmental Geology 31 (3/4).

Rakovec, J., 2020: Impact of visits on microclimate of caves - An analytical approach.- Acta Carsologica 49/1 - 2020, 97 - 107. https://doi.org/10.3986/ ac.v49i1.8721

Ruan, J. Y. \& C. Y. Hu, 2010: Seasonal variations and environmental controls on stalagmite calcite crystal growth in Heshang Cave, central China.- Chinese Science Bulletin, December 2010, Vol. 55, No. 34, 3929 - 3935. http://dx.doi.org/10.1007/s11434-0104193-1

Salerno, F., Viviano, G., Manfredi, E. C., Caroli, P., Thakuri, S. \& G. Tartari, 2013: Multiple carrying capacities from a management-oriented perspective to operationalize sustainable tourism in protected areas.- Journal of Environmental Management 128 (2013), 116 - 125. https://doi.org/10.1016/j.jenvman.2013.04.043 
Spate, A., 2004: The green sickness - la maladie verts or Lampenflora.- ACKMA Journal No. 54, 24 - 27.

Šebela, S. \& J. Turk, 2011: Local characteristics of Postojna Cave climate, air temperature, and pressure monitoring.- Theoretical and Applied Climatology, 105, 371-386, Springer, https://doi.org/ 10.1007/ s00704-011-0397-9

Tičar, J., Tomić, N., Valjevac Breg, N., Zorn, M., Marković, S. B \& M. B. Gavrilov, 2018: Speleotourism in Slovenia: balancing between mass tourism and geoheritage protection. Open Science, Volume 10: Issue 1, DOI: https://doi.org/10.1515/geo-2018-0027
Van der Donk, M. \& S. Cotrell, 2002: Developing a visitor management framework for WWF's PAN parks project - case study of a national park in France.In: Arnberg, A. et al. (eds.) Monitoring and Management of Visitor Flows in Recreational and Protected Areas. Conference proceedings, Bodenkultur University Vienna, Austria, 320 - 327, Wien.

Zelinka, J., 2002: Microclimatic research in the Slovakian Show Caves.- Acta Carsologica, 31/1, 12, 151 - 163. https://doi.org/10.3986/ac.v31i1.410

Zupan Hajna, N., 2006: Siga v kraških jamah.- Scopolia Suppl. 3., $192-2013$. 